\title{
Taxonomic guide and historical review of starfishes in northeastern Brazil (Echinodermata,Asteroidea)
}

\author{
Anne Isabelley Gondim', Martin Lindsey Christoffersen', \\ Thelma Lúcia Pereira Dias
}

I Universidade Federal da Paraíba, Programa de Pós-Graduação em Ciências Biológicas (Zoologia), Departamento de Sistemática e Ecologia, Laboratório de Invertebrados Marinhos Paulo Young, Bairro Cidade Universitária s/n, CEP. 58059-900, João Pessoa, PB, Brasil 2 Universidade Estadual da Paraíba, CCBS, Departamento de Biologia, Laboratório de Biologia Marinha, Campus I, Rua Baraúnas, 351, Bairro Universitário, CEP 58429-500, Campina Grande, PB, Brasil

Corresponding author: Anne Isabelley Gondim (anneisabelley@yahoo.com.br)

Academic editor: Y. Samyn | Received 15 December 2013 | Accepted 8 October 2014 | Published 22 October 2014

http://zoobank.org/75DDC584-63EB-4BF1-BBF9-08C1D2954CAC

Citation: Gondim AI, Christoffersen ML, Dias TLP (2014) Taxonomic guide and historical review of starfishes in northeastern Brazil (Echinodermata, Asteroidea). ZooKeys 449: 1-56. doi: 10.3897/zookeys.449.6813

\begin{abstract}
Presently more than 1900 species of sea stars are recognized, of which 77 are recorded for the coast of Brazil. Although the first starfish record in Brazil was published 363 years ago, our knowledge of this fauna remains unsatisfactory from a systematic and ecological point of view, particularly in the north and northeastern regions of the country. This study provides the first annotated list of sea stars from northeastern Brazil. Material described herein is housed at the collections of the Federal University of Paraíba, Federal University of Sergipe, and the Federal University of Bahia, Museum of Zoology of the University of São Paulo and Museu Nacional do Rio de Janeiro. Twenty-one species were identified, belonging to 12 genera, 10 families, and 5 orders. Descriptions of species are provided. Three new occurrences were recorded for northeast Brazil: Astropecten alligator, Luidia ludwigi scotti, and Mithrodia clavigera. Highest diversities of Asteroidea were encountered for the states of Bahia ( $\mathrm{n}=14 \mathrm{spp})$, Paraíba ( $\mathrm{n}=12 \mathrm{spp}$ ) and Pernambuco ( $\mathrm{n}$ = 9 spp). No species were recorded for the states of Maranhão and Sergipe. Sandy substrates and depths below $10 \mathrm{~m}$ were the least sampled areas over the continental shelf. Herein we provide a first panorama on the fauna of Asteroidea occurring in the northeast region of Brazil, hopefully to function as a basic reference for biodiversity studies in this poorly studied area.
\end{abstract}

\section{Keywords}

Echinoderms, taxonomy, check list, sea-stars, northeastern Brazil

Copyright Anne Isabelley Gondim et al. This is an open access article distributed under the terms of the Creative Commons Attribution License (CC BY 4.0), which permits unrestricted use, distribution, and reproduction in any medium, provided the original author and source are credited. 


\section{Introduction}

The Asteroidea represent the second most diverse group within the phylum Echinodermata, with an estimated number of 1900 living species (Mah and Blake 2012). Of these, 77 species are recorded for the Brazilian coastline (Ventura et al. 2012).

The first paper to deal with the Echinodermata of the Brazilian littoral was published by Georg Marcgraf (1648) and entitled "Natural History of Brazil". In this work, animals observed from an expedition to northeast Brazil during the stay of the Count of Nassau are described, sometimes in a rather fanciful way (Hadel et al. 1999). Among the diverse groups described and illustrated by Marcgraf are two species of starfish (Luidia senegalensis as Stella senegalensis, and Oreaster reticulatus). Later C. F. Hartt collected 16 species of echinoderms from Abrolhos (Bahia), of which four were asteroids (Oreaster reticulatus, Linckia guildingi, Echinaster (Othilia) echinophorus, and Coscinasterias tenuispina) (Verrill 1868). Between 1875 and 1877 this same author collected another 62 species of echinoderms, which were described by Rathbun (1879). That paper furnished the first list of echinoderms from Brazil and in it 12 species of asteroids were recorded.

Thirty six years after the paper by Rathbun (1879), Verrill (1915) published a new list with descriptions and illustrations of 125 species of sea-stars from the West Indies, Florida, and Brazil. Later H. P. Oliveira (1940) furnished a new list of the Brazilian asteroids. Since then, several contributions on the marine benthic fauna were published by diverse authors, which increased our knowledge of the Brazilian asteroids. Concomitantly, several papers were published on the Echinodermata from Brazil by Dr. Luiz Roberto Tommasi. The paper published by Tommasi (1970) is his main contribution to the Class Asteroidea. In this work he produced descriptions and illustrations of the 42 species then known for the coast of Brazil.

After these pioneer studies, several works focusing on taxonomy, ecology and geographical distribution were developed, mainly in the south and southeast (e.g. Brito 1960, Carrera-Rodríguez and Tommasi 1977, Monteiro and Pardo 1991, Ventura and Fernandes 1995, Ventura et al. 1997, Nobre and Campos-Creasey 2000, Alves et al. 2002, Carvalho and Ventura 2002, Gibran 2002, Calil et al. 2009, Mariante et al. 2010).

For northeast Brazil, only three papers have focused on the Asteroidea: Lima-Verde and Matthews (1969), who studies the feeding habits of Luidia senegalensis in the State of Ceará; Manso (2006), who recorded the first Goniasteridae for the Potiguar Basin in the Cretaceous of Brazil, and Matthews and Lima-Verde (1969), who furnished ecological information on Oreaster reticulatus from the northeastern region. Knowledge on diversity along the northeastern littoral stems from species inventories. Among these: Lima-Verde (1969) recorded seven species along Ceará, Rio Grande do Norte, Pernambuco and Alagoas; Tommasi (1970) recorded six species for several northeastern states; Tommasi and Aron (1988) expanded to ten the known species from Bahia; Fernandes et al. (2002) record six species from Pernambuco; Magalhães et al. (2005) cited eight species for Bahia; Gondim et al. (2008) recorded five species for Paraíba; Gondim and Giacometti (2010) and Gondim et al. (2013) signaled two species for the coast of Piauí; and Miranda et al. (2012) recorded eight species from Alagoas. 
Northeastern Brazil has a coastline with $3,400 \mathrm{~km}$ in extension (Pinheiro et al. 2008), which represents $42.5 \%$ of the entire Brazilian coastline. This region contains a great variety of ecosystems and has one of the largest reef environments of the Southwestern Atlantic Ocean. Notwithstanding, many areas remain unexplored (Marques and Lamas 2006) and our knowledge of the macrozoobenthos below $20 \mathrm{~m}$ is still limited, mainly regarding the outer platform and the continental slope (Migotto and Tiago 1999). Brazil has organized few marine expeditions (an example being the Programa de Avaliação do Potencial Sustentável de Recursos Vivos na Zona Econômica Exclusiva - REVIZEE), but most results continue concentrated in the south and southeastern regions, the addition of information for the north and northeastern regions being minimal below $20 \mathrm{~m}$ depth (Marques and Lamas 2006).

Although the first record of the Asteroidea for the Brazilian littoral was made about 363 years ago, the knowledge of this fauna in the north and northeastern regions still remains unsatisfactory and punctual, from both a systematic and an ecological point of view. The aim of the present work is to expand our knowledge on the morphology of the species of Asteroidea from northeastern Brazil.

\section{Materials and methods}

Species determinations were based mainly on Tommasi (1970), Clark and Downey (1992), and Hendler et al. (1995). Synonyms were compiled from Tommasi (1970), Clark and Downey (1992), and Mah (2013). We provide a reference to the first work mentioning the synonym and to the main papers on the Brazilian fauna that subsequently cite the species.

Illustrations are based on photos made with a Canon A640 10MP camera coupled with a Nikon stereomicroscope. Morphometrics were recorded with a digital EDC 6 caliper ruler.

The studied material is conserved in $70 \%$ alcohol or preserved dry and registered in the visited collections.

\section{Study area}

The littoral region of northeast Brazil extends for approximately 3,400 km (Pinheiro et al. 2008), beginning in the Parnaíba River Delta and extending first to the east and then to the south up to the border of between the States of Bahia and Espírito Santo. The region encompasses nine coastal States: Maranhão, Piauí, Ceará, Rio Grande do Norte, Paraíba, Pernambuco, Alagoas, Sergipe, and Bahia (Fig. 1).

The region has a great diversity of littoral environments, such as beaches, dunes, cliffs, estuaries, deltas, sandbanks, reefs and underwater biotopes, such as rhodolith beds, seagrass beds and coral habitats (Fig. 2). They share Tertiary sediments from the Barreiras Formation, beach rocks, and coral reefs (Suguio 2003). This coastal diversity, allied to 


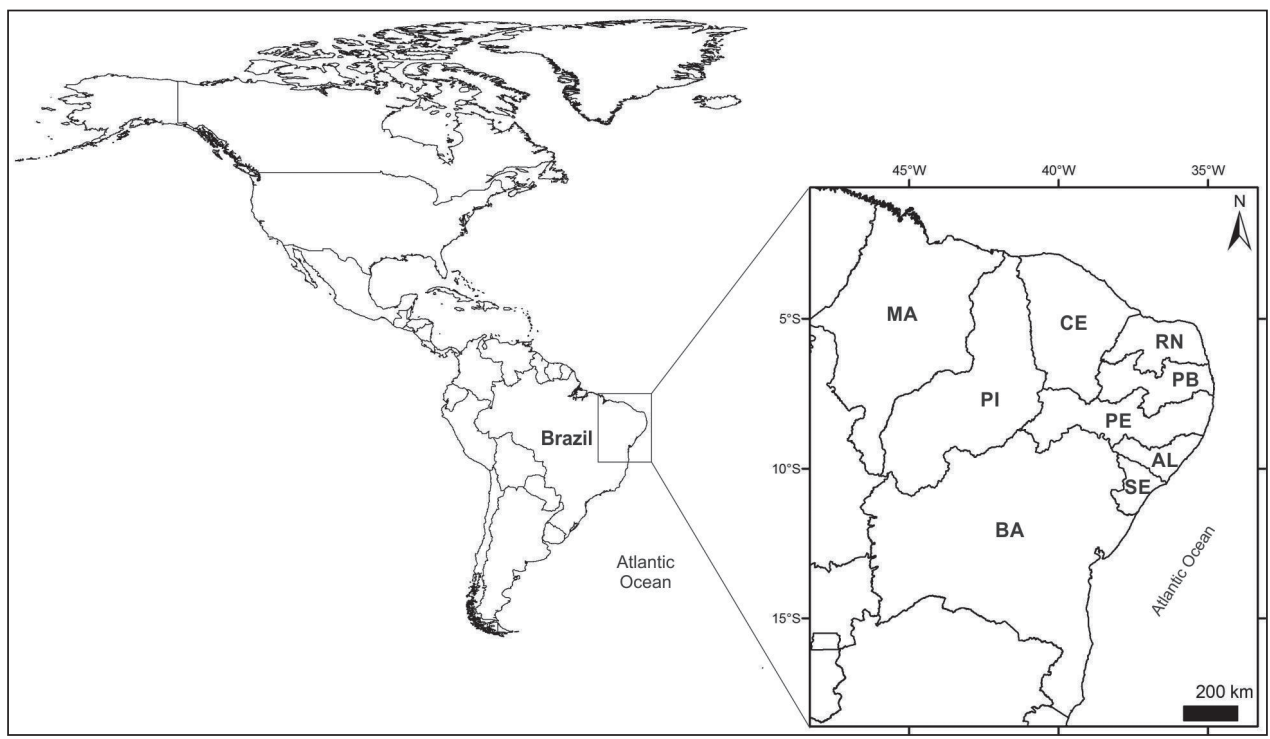

Figure I. Map of the Americas showing the northeast region of Brazil divided in the nine states. MA Maranhão PI Piauí CE Ceará RN Rio Grande do Norte PB Paraíba PE Pernambuco AL Alagoas SE Sergipe, and BA Bahia.

the favorable climatic conditions and year-round warm waters, makes this region one of the most important tourist destinations in the country (Pinheiro et al. 2008).

Due to the absence of large rivers and to the predominance of warm waters from the South Equatorial Current, offshore conditions in the northeast region are ideal for the formation of coastal coral reefs (Maury 2002). The most common formations along the coast are arenitic beach rocks (Mabesoone and Coutinho 1970), which harbour scleractinian corals and calcarious algae. Reefs composed exclusively of calcarious algae and corals also occur commonly. At the South of the State of Bahia, singular mushroom-shaped coral-reef formations, denominated locally as "chapeirôes", are present offshore (Abrolhos region).

The northeastern continental shelf is narrow and shallow. Due to the reduced continental influence and to the tropical climate, an important sedimentation of biogenic carbonates dominates most of the middle and outer platform, particularly between Macau (RN) and Maceió (AL) (Coutinho 2006). The platform ends very abruptly around depths of 60-80 m. The isobath of $20 \mathrm{~m}$ coincides mostly with the extent of the platform. The continental shelf may reach an extent of 60 miles at Cape São Roque (RN), and less than 5 miles in front of Recife (PE) (Kempf et al. 1970).

The biogenic carbonates form sand and gravel, consisting mainly of incrusting and ramified calcareous algae, with local occurrences of Halimeda spp. These sediments may contain up to $5 \%$ of carbonatic mud derived from the desintegration of larger organisms. In certain areas, these sediments undergo a process of litification, also affecting the quartsoze sands of the inner platform, originating the extensive coastal reefs known as beach rocks. These then become overgrown by algae and corals (Lana et al. 1996). 

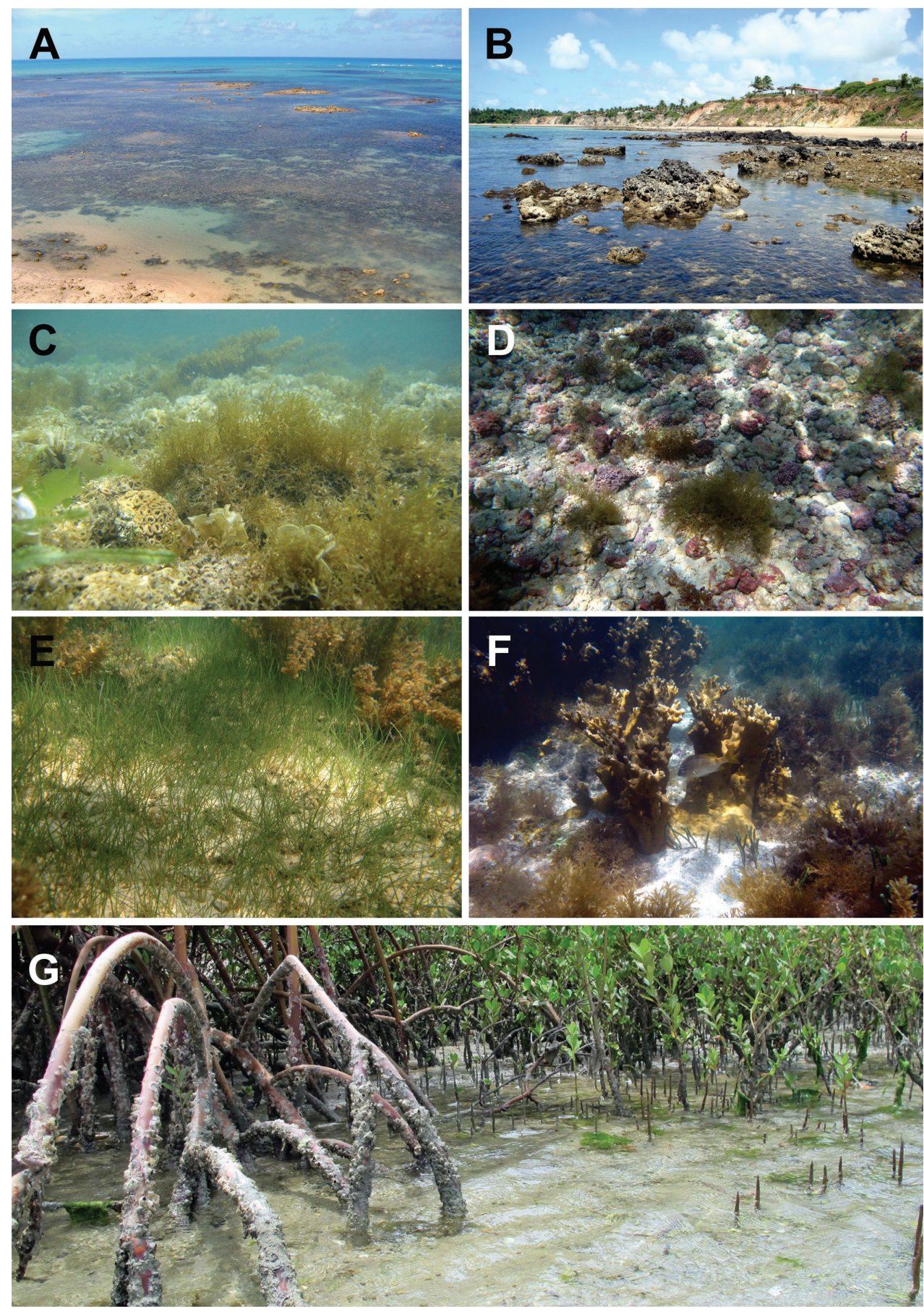

Figure 2. Some littoral environmnets and shallow-water biotopes used as habitats by sea stars in northeastern Brazil. A Fringing reef B Beach rocks C Algae banks D Rhodolith bed E Seagrass bed $\mathbf{F}$ Patch reef, and $\mathbf{G}$ Mangroves. Photos: Thelma LP Dias. 
Abbreviations: Brazilian states - Ceará (CE), Piauí (PI), Rio Grande do Norte (RN), Paraíba (PB), Pernambuco (PE), Bahia (BA), Paraná (PR), Rio de Janeiro (RJ), Rio Grande do Sul (RS), Santa Catarina (SC), São Paulo (SP).

Acronyms: UFPB.Ech: Echinodermata Collection from Universidade Federal da Paraíba. MZUFBA: Museum of the Federal University of Bahia. MZUSP: Museum of Zoology of the University of São Paulo. MNRJ: National Museum of Rio de Janeiro.

\section{Results}

A total of 21 species, belonging to five orders, 10 families and 12 genera were identified. These are listed and described below, following the taxonomic organization of Clark and Downey (1992).

\section{Checklist of Starfishes from northeastern Brazil}

Phylum Echinodermata Brugière, 1791

Class ASTEROIDEA de Blainville, 1830

Order Paxillosida Perrier, 1884

Family Luidiidae Verrill, 1900

Luidia alternata alternata (Say, 1825)

Luidia clathrata (Say, 1825)

Luidia ludwigi scotti Bell, 1917

Luidia senegalensis (Lamarck, 1816)

Family Astropectinidae Gray, 1840

Astropecten acutiradiatus Tortonese, 1956

Astropecten alligator Perrier, 1881

Astropecten brasiliensis Müller \& Troschel, 1842

Astropecten cingulatus Sladen, 1833

Astropecten duplicatus Gray, 1840

Astropecten marginatus Gray, 1840

Order Valvatida Perrier, 1884

Family Asterinidae Gray, 1840

Asterinides folium (Lütken, 1860)

Family Mithrodiidae Viguier, 1878

Mithrodia clavigera (Lamarck, 1816)

Family Oreasteridae Fisher, 1911

Oreaster reticulatus (Linnaeus, 1758)

Family Goniasteridae Forbes, 184

Nymphaster arenatus (Perrier, 1881)

Plinthaster dentatus (Perrier, 1884)

Order Velatida Perrier, 1884 
Family Pterasteridae Perrier, 1875

Calyptraster coa Sladen, 1882

Family Ophidiasteridae Verrill, 1870

Linckia guildingi Gray, 1840

Narcissia trigonaria Sladen, 1889

Order Spinulosida Perrier, 1884

Family Echinasteridae Verrill, 1867

Echinaster (Othilia) brasiliensis Müller \& Troschel, 1842

Echinaster (Othilia) echinophorus (Lamarck, 1816)

Order Forcipulatida Perrier, 1884

Family Asteriidae Gray, 1840

Coscinasterias tenuispina (Lamarck, 1816)

\section{Systematics}

\section{Order Paxillosida Perrier, 1884 \\ Family Luidiidae Sladen, 1889}

\section{Luidia alternata alternata (Say, 1825)}

Figure $3 \mathrm{a}-\mathrm{d}$

Asterias alternata Say, 1825: 144-145.

Luidia alternata Lütken, 1859: 42-43. Brito 1968: 12-13, pl. 3, fig. 4. Tommasi 1970:

8, fig. 24. Tommasi and Aron 1987: 5. Tommasi et al. 1988: 6. Ventura et al. 2007:

236. Miranda et al. 2012: 9.

Luidia granulosa Perrier, 1869: 109-110, pl. 2, fig. 18.

Luidia variegata Perrier, 1875: 337.

Luidia numidica Koehler, 1911: 3, pl. 1, figs 8-11.

Luidia quequenensis Bernasconi, 1942: 253. Tommasi 1970: 8, fig. 23. Carrera-Rodriguez and Tommasi 1977: 62, 65.

Luidia bernasconiae A.H.Clark, 1945: 19-21.

Luidia alternata var. numidica Madsen, 1950: 206-209, fig. 9.

Luidia alternata numidica A.M.Clark, 1953: 388-389, pl. 41, fig. 1.

Luidia alternata alternata Clark \& Downey, 1992: 8-9; Magalhães et al. 2005: 63.

Material examined. Paraíba: 646'S; 34ํำ'W, 1spec., UFPB/ECH.877, 13.II.1981, $14 \mathrm{~m} ; 7^{\circ} 01^{\prime} \mathrm{S} ; 34^{\circ} 41^{\prime} \mathrm{W}, 1 \mathrm{spec}$. UFPB/ECH.876, 13.II.1981, 24m; 704"S; 34 $41^{\prime} \mathrm{W}$, 1spec., UFPB/ECH.879, 16.II.1981, 22m.

Type locality. Dry Tortugas, Florida Keys, Florida (Clark and Downey 1992)_ Neotype.

Description. Body pentagonal (Fig. 3a, b). Five elongate and thin arms. Abactinal surface with paxillae (Fig. 3a). Carinal paxillae smaller than adradial paxillae, with 1-4 


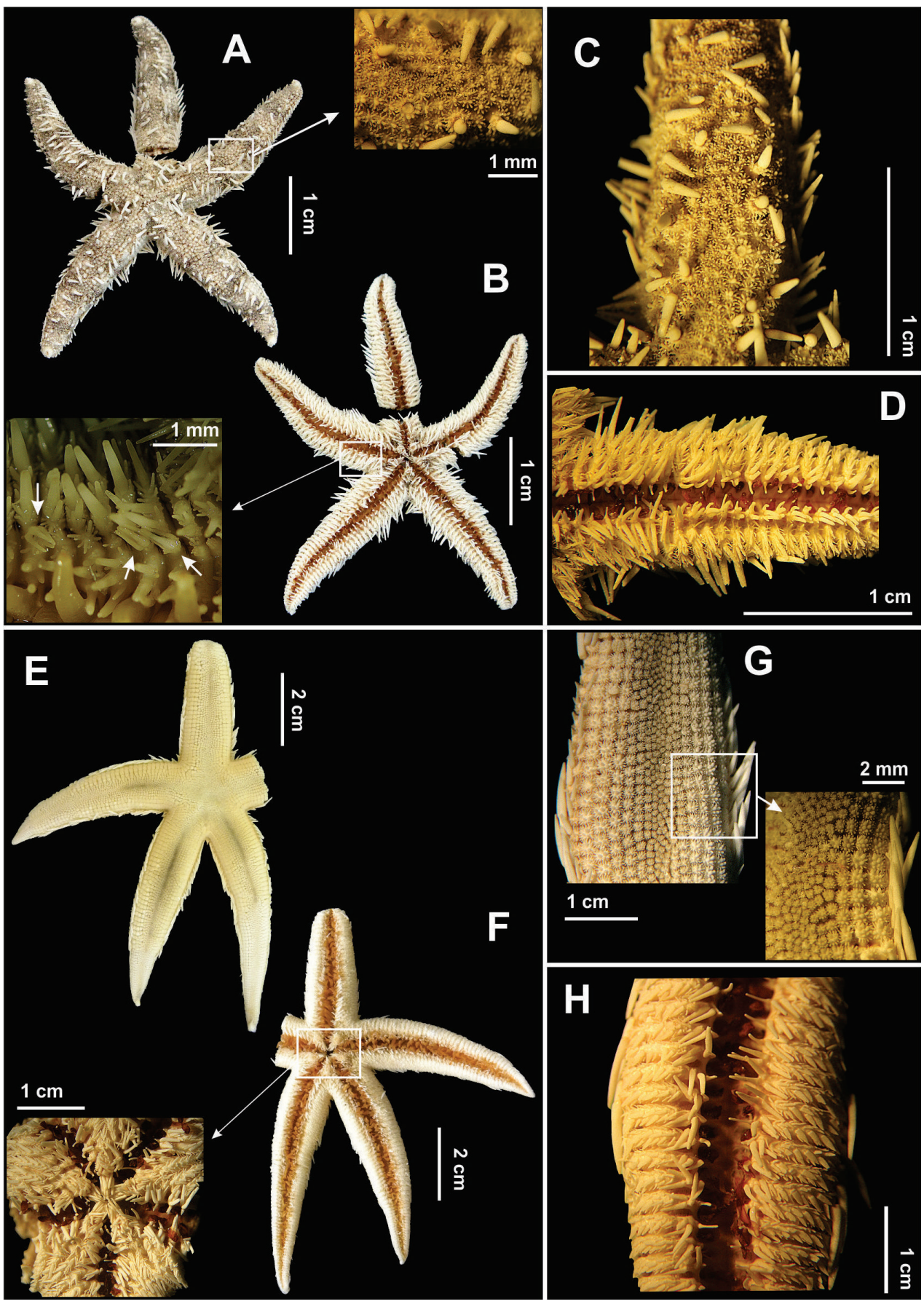

Figure 3. Some species of the family Luidiidae recorded in northeastern Brazil. Luidia alternata alternata (A-D). A Abactinal view, in detail the paxilla B Actinal view, in detail the pedicellariae $\mathbf{C}$ Abactinal view of the arm $\mathbf{D}$ Actinal view of the arm; Luidia clathrata $(\mathbf{E}-\mathbf{H}) \mathbf{E}$ Abactinal view $\mathbf{F}$ Actinal view, in detail the mouth $\mathbf{G}$ Abactinal view of the arm, in detail the paxilla, and $\mathbf{H}$ Actinal view of the arm. 
blunt central spinelets and with one or two series of marginal spinelets, numbering 12-20 per series. One of the central spines is slightly longer than remaining spines. Paxillae rounded and arranged into regular transversal rows. Some adradial paxillae with one long, conical and pointed central spine $(-1.90 \mathrm{~mm})$ (Fig. 3c). Inferomarginal plate with 1 or 2 long, thin spines $(-1.76 \mathrm{~mm})$, placed vertically and forming a well defined marginal row. Actinal surface with inferomarginal plates densely covered with spines of diverse shapes and sizes, there being 1-3 longer spines located centrally (Fig. $3 c, d)$. Adambulacral plate with 4 spines placed vertically. The adambulacral spine is the smallest, being slightly curved and compressed. The two subambulacral spines are subequal in shape and size. A short spine is located laterally to the most external spine. Oral spines narrow and elongate. With bi, tri and tetravalvular pedicellariae on actinal surface (Fig. 3b).

Colour. Abactinal surface white or cream-coloured, with dark transversal bands. The colour of these bands varies, and may be brown, black, green, or purple. Actinal surface whitish or beige.

Distribution. North Carolina, the Bahamas, Florida, Gulf of Mexico, Cuba, Jamaica, Honduras, Puerto Rico, Panama, Colombia, Venezuela, Brazil, Uruguay, and Argentina (Bernasconi 1943, Tommasi 1958, Downey 1973, Walenkamp 1976, Clark and Downey 1992, Hendler et al. 1995, Ventura et al. 2007, Alvarado et al. 2008). In Brazil from AL, BA, RJ, and SP (Verrill 1915, Brito 1962, 1968, Tommasi 1970, Magalhães et al. 2005, Miranda et al. 2012). This is the first record of the species for the coast of Paraíba. From 1 to $200 \mathrm{~m}$ in depth (Clark and Downey 2002), most common between 10 and $30 \mathrm{~m}$.

Remarks. The main characters distinguishing Luidia alternata alternata from the remaining species of the genus that occur in the Western Atlantic are their colour and the presence of long conical spines on the adradial paxillae. The abactinal colouration is distinctive. The nominal subspecies differs from its congeneric form Luidia alternata numidica Koehler, 1911, from West Africa, for attaining a larger size and for having longer paxillar spines. Clark (1982) provided a good discussion on the synonymy of the nominal subspecies and designates a neotype. Specimens analysed in this study are young individuals that may attain $200 \mathrm{~mm}$ along its larger ray. Furthermore, our specimens presented no morphological variations, agreeing with the descriptions of this species. Despite not receiving much attention in recent taxonomic surveys, pedicellariae are an important taxonomic character to distinguish species of asteroids. Clark (1982) and Clark and Downey (1992) furnished excellent illustrations of the species of Luidia known from the Atlantic.

Ecological notes. This subspecies is primarily associated with sandy and muddy bottoms. It may also be found in mangroves or associated with fragments of shells and calcareous algae (Clark and Downey 1992, Benavides-Serrato et al. 2011). According to Hendler et al. (1995), the subspecies does not occur in large numbers, but is often found among the accompanying fauna in trawling nets. L. alternata alterna is carnivorous, feeding on epifaunal organisms, especially other echinoderms. 


\section{Luidia clathrata (Say, 1825)}

Figure $3 \mathrm{e}-\mathrm{h}$

Asterias clathrata Say, 1825: 142.

Luidia clathratta Lütken, 1859: 37-39. Rathbun 1879: 150. Bernasconi 1943: 6-7.

Tommasi 1970: 8. Magalhães et al. 2005: 63.

Luidia clathrata Lütken, 1859: 37. Tommasi 1958: 9, pl. 2, fig. 1; 1970: 8, fig. 22.

Brito 1962: 4; 1968: 11-12, pl. 2, fig. 2. Carrera-Rodriguez and Tommasi 1977:

63-64. Tommasi and Aron 1987: 3. Tommasi et al. 1988: 6. Magalhães et al. 2005: 63. Ventura et al. 2007: 237. Manso et al. 2008: 185, fig. 7a-e. Lima and Fernandes 2009: 58. Xavier 2010: 75.

Material examined. Paraíba: 6057'S; 34²1'W, 2 spec., UFPB/ECH.875, 12.II.1981, 26m.

Type locality. Probably no longer existant (Clark and Downey 1992).

Description. Five long and narrow arms (Fig. 3e, f). Abactinal surface paxillar. Lateral paxillae quadrangular, forming three regular rows (Fig. 3g). Carinal paxillae small, smaller than lateral paxillae. Dorsal paxillae rounded, small, with 1-6 short, blunt, central spinelets and 6-18 slender, marginal spinelets. Inferomarginal plates with two long, pointed, conical spines $(-2.58 \mathrm{~mm})$, positioned vertically, the inferior one the largest. Actinal surface with inferomarginal plates densely covered with flattened, lanceolate spines (Fig. 3f). A row of short, actinolateral plates, with 1-3 short, lanceolate, divergent spines. Ambulacral plates with three spines placed vertically (Fig. $3 \mathrm{~h})$. The adambulacral spine is the smallest, being slightly curved and compressed. Of the two subambulacral spines, the inner one is longer and thicker than the outer spine. Oral spines long $(-1.32 \mathrm{~mm})$, thin and pointed, forming dense tufts on the inner angle of the jaw (Fig. 3f). Ocular plate granulose and elongate.

Colour. Abactinal surface bluish-gray, frequently with a darker line occupying the carinal region of the arm and disk. Hendler et al. (1995) cite other colour patters for the abactinal surface: brown, rose and salmon. Actinal surface white or creamcoloured.

Distribution. Bermuda, Gulf of Mexico, Belize, Honduras, Nicaragua, Panama, Colombia, Venezuela, and Brazil (Downey 1973, Clark and Downey 1992, Hendler et al. 1995, Alvarado et al. 2008, Benavides-Serrato et al. 2005). In Brazil: PE, BA, RJ, SP, and SC (Rathbun 1879, Bernasconi 1943, Tommasi 1958, 1970, Brito 1960, 1962, Walenkamp 1976, Magalhães et al. 2005, Lima and Fernandes 2009, Xavier 2010). This study records the species for the first time in the State of Paraíba. From intertidal to $175 \mathrm{~m}$ in depth (Ventura et al. 2007), being most common in depths under $40 \mathrm{~m}$ (Hendler et al. 1995).

Remarks. Luidia clathrata differs from L. alternata alternata for not having the abactinal surface spinulose. It differs from $L$. senegalensis for having only 5 arms and from L. ludwigi scotti for not having pedicellariae. According to Walenkamp (1976), the number of central spinelets on the paxillae and of inferomarginal spines increases with ontological development, the maximum numbers being, respectively, 7 and 3. In 
this study the examined specimen had only two inferomarginal spines, and 1-6 central spinelets on the paxillae. These characters indicate a juvenile individual. According to Hendler et al. (1995), adult individuals may attain 20 to $30 \mathrm{~cm}$ in disk diameter. Knott and Hopkins (1998) recognized two morphotypes of L. clathrata for the Colombian Caribbean, one with a gray colour and the other with three colours, which were separated by Hopkins and Knott (2010) into L. clathrata and L. lawrencei. Those authors also established and described a neotype for $L$. clathrata.

Ecological notes. This species lives in sandy or muddy areas with low hydrodynamism near the coast, such as bays and lagoons, and is also found in mangroves and regions with low salinity. Further away from the coast, it lives in substrates with sand, mud and gravel (Machado et al. 2008, Benavides-Serrato et al. 2011). It feeds on a great variety of prey, including molluscs, crustaceans, and ophiuroids (Hendler et al. 1995). Like L. alternata and L. senegalensis, Ludia clathrata is host for the small polychaete Podarke obscura Verrill, 1873, that lives in the interior of its ambulacral groove. L. clathrata may form dense populations, and is thus frequently captured in trawling nets used in shrimp fisheries (McClintock and Lawrence 1985, Hendler et al. 1995). Presently it is considered to be a species vulnerable to extinction along the Brazilian coast (Machado et al. 2008).

\section{Luidia ludwigi scotti Bell, 1917}

Figure 4a-d

Luidia scotti Bell, 1917: 8-9. Tommasi 1970: 8, fig. 25. Carrera-Rodriguez and Tommasi 1977: 62, 65-66.

Luidia doello-juradoi Bernasconi, 1941: 117; 1943: 8-11. Brito 1962: 3.

Luidia rosaurae Jonh \& Clark, 1954: 142-145.

Luidia doello-juradol Brito, 1968: 12, pl. 3, fig. 5.

Luidia ludwigi Walenkamp, 1976: 32-37, fig. 9, pl. 2, figs 1-3, pl.4, fig. 3. Machado et al. 2008: 179-180. Xavier 2010: 75.

Luidia ludwigi scotti A.M.Clark, 1982: 171-173. Tommasi 1985: 3. Tommasi et al. 1988: 6. Manso 1989: 357.

Luidia rosaurae John \& Clark, 1954: 142-145, pl. 6, fig. 1.

Material examined. Paraíba: $6^{\circ} 39^{\prime} 05^{\prime \prime S}$; $34^{\circ} 49^{\prime} \mathrm{W}, 1$ spec., UFPB/ECH.878, 28.V.1981, 20m.

Type locality. Rio de Janeiro, Brazil (Clark and Downey 1992).

Description. Body flattened. Five arms that taper gradually towards their extremities (Fig. 4a, b). Abactinal surface with paxillae (Fig. 4a). Dorsal paxillae small, ordered, with 1-6 central, short, blunt spinelets, and 18 marginal, slender, and denticulate spinelets (Fig. 4c). Adradial paxillae rectangular or quadrangular, slightly larger than the carinal paxillae. Inferomarginal plates with one pointed, elongate spine $(-2.04$ $\mathrm{mm}$ ) forming the marginal fringe (Fig. 4a). The remaining part of the plate is covered 


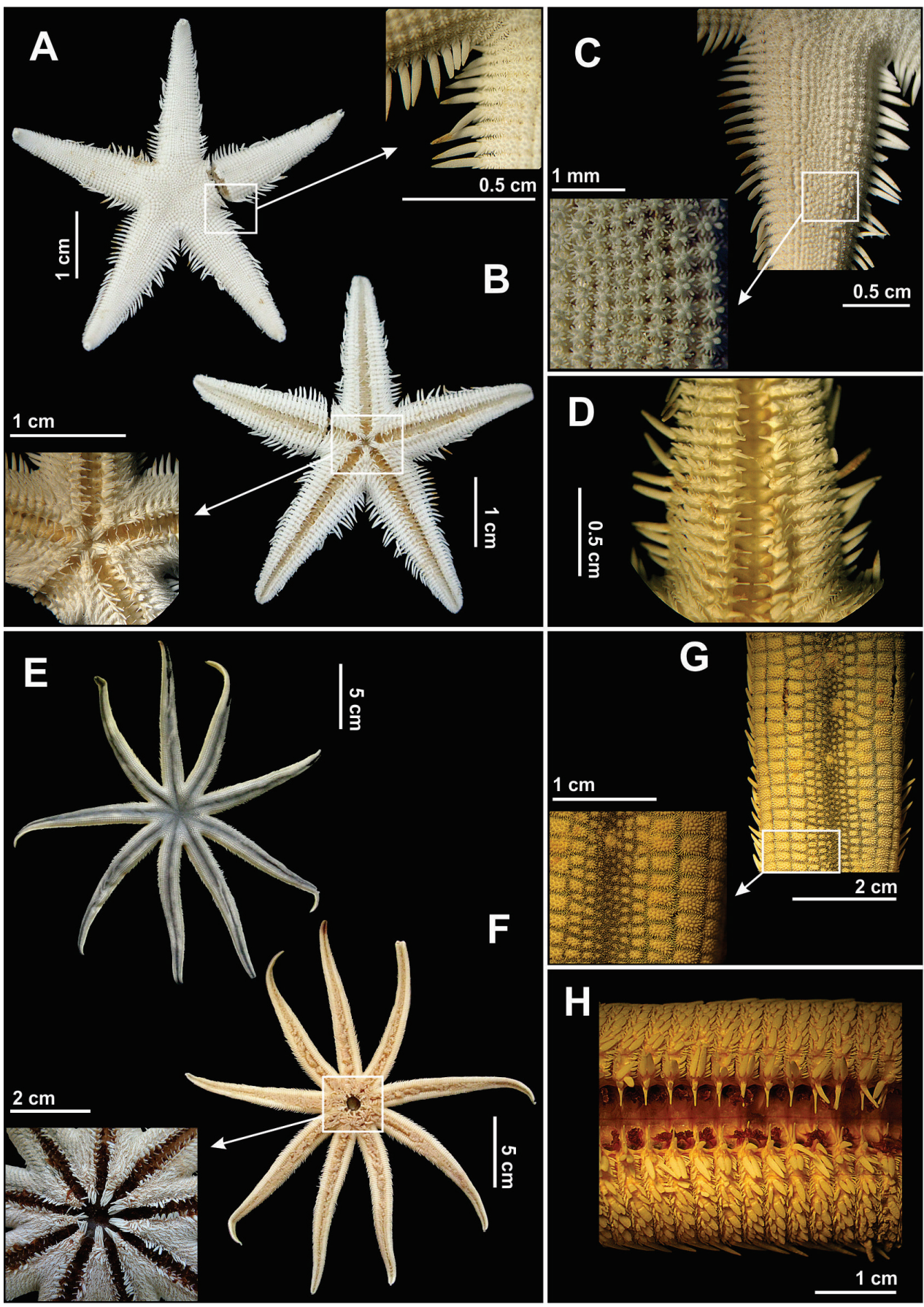

Figure 4. Some species of the family Luidiidae recorded in northeastern Brazil. Luidia ludwigi scotti (A-D) A Abactinal view, in detail abactinal intermediate area $\mathbf{B}$ Actinal view, in detail the mouth $\mathbf{C}$ Abactinal view of the arm, in detail the paxilla $\mathbf{D}$ Actinal view. Luidia senegalensis $(\mathbf{E}-\mathbf{H}) \mathbf{E}$ Abactinal view $\mathbf{F}$ Actinal view, in detail the mouth $\mathbf{G}$ Abactinal view of the arm, in detail the paxilla, and $\mathbf{H}$ Actinal view of the arm. 
by short, hyaline and denticulate spinelets. Actinal surface with inferomarginal plates, densely covered by flattened and lanceolate spines (Fig. b, d). Actinolateral plate with three short, slender, divergent spines. The median of these is the largest. The ambulacral spine long, flattened and slender (Fig. 4d). Bivalved pedicellariae present only on the actinal surface, mainly on the ventro-lateral plates and in the areas close to the arms, never occurring on the abactinal surface. Oral spines slender, long $(-1.18 \mathrm{~mm})$ with blunt tip, forming a bundle of spines at apex of jaw (Fig. 4c).

Colour. The colour pattern on the aboral surface of the body is very variable. Some specimens may be whitish with black spots on arms, others are brown with white spots on arms. Most, however, have the arms more or less banded with alternating white and brown stripes (Walenkamp 1976). Benavides-Serrato et al. (2011) and Clark and Downey (1992) observed specimens with dark pink spots in the center of the dorsal surface of the disc and transversal bands of the same tone on the arms. Oral surface with colour varying between white and cream. When observed in alcohol they are uniformly white.

Distribution. Florida, Gulf of Mexico, Colombia, Venezuela, Guyana, French Guyana, Brazil, and Argentina (Mar del Plata) (Bernasconi 1943, Tommasi 1970, Clark and Downey 1992, Benavides-Serrato et al. 2005). In Brazil: RJ, SP, and SC (Brito 1962, 1968, Xavier 2010). This is the first record of the species for the littoral of northeast Brazil. From 20 to $126 \mathrm{~m}$ in depth. Clark and Downey (1992) considered the previous record at $5 \mathrm{~m}$ for the State of São Paulo to be doubtful. Thus the present study expands the bathymetric distribution to $20 \mathrm{~m}$ deep, previously established at 33-126 m.

Remarks. This subspecies may be distinguished from other taxa in the genus by the presence of pedicellariae with three or four well-developed valves on the actinal surface, the delicate structure of the paxillae, and the slightly triangular shape of the arms, which become narrow distally. Luidia clathrata is similar to L. ludwigi scotti, but may be distinguished from it by having a stronger actinal skeleton and by the absence of pedicellariae. The synonymy between Luidia rosaurae John \& Clark, 1954 and $L$. scotti was proposed by Clark (1982), who observed that the differences in the inferomarginal spines previously established between the two species were insignificant and unable to support the independence of the two species. Furthermore, with the observations of Walenkamp (1976) that $L$. rosaurae is conspecific with L. ludwigi Fisher, 1906, Clark and Downey (1992) recognized the subspecies Luidia ludwigi scotti for specimens from the Atlantic, as these have a paxillar arrangement that is distinct from the remaining species previously cited. According to Clark and Downey (1992), the relationships between $L$. patriae Bernasconi, 1941 and this subspecies still need to be investigated. The specimen analised in this study, even though representing a juvenile individual, did not present significant morphological variations when compared with the characters described for adult specimens, indicating that the morphological characters of $L$. ludwigi scotti do not vary significantly during ontogeny.

Ecological notes. This subspecies occurs in non-consolidated sediments containing fine or coarse sand (Machado et al. 2008). In contrast to other taxa of Luidia, which 
do not present prey selectivity, in Luidia ludwigi scotti only eight different food types have been recorded, of which bivalves, foraminiferans and ophiuroids are their main prey (Benavides-Serrato et al. 2011). The presence of different prey species of distinct sizes in the stomachs of $L$. ludwigi scotti probably reflects a response to competition and coexistence with other species of sea-stars (Brögger and Penchaszadeh 2008).

\section{Luidia senegalensis (Lamarck, 1816)}

Figures $4 \mathrm{e}-\mathrm{h}, 12 \mathrm{a}$

Asterias senegalensis Lamarck, 1816: 567.

Luidia senegalensis Müller \& Troschel, 1842: 78. Tommasi 1958: 9, pl. 2, fig. 1; 1970:

8, fig. 21; 1985: 3. Brito 1968: 10-11, pl. 3, fig. 1. Lima-Verde 1969: 10. Nomura and Fausto Filho 1966: 19. Fernandes et al. 2002: 422. Magalhães et al. 2005: 63. Manso et al. 2008: 185, fig 8c-e. Lima and Fernandes 2009: 58. Xavier 2010: 75. Luidia marcgravii Steenstrup in Lütken 1859: 43-46.

Material examined. Rio Grande do Norte: Timbau Beach, 3 spec., UFPB/ECH.1582, 28.II.1980; Areia Branca, Ponta do Mel, 1spec., UFPB/ECH.1428, 23.VI.1982. Paraíba: Lucena, Costinha Beach, 5 spec., UFPB/ECH.1673, 08.XI.2003; Cabedelo, Miramar Beach, 4spec., UFPB/ECH.1256, 03.II.1983; Cabedelo, Santa Catarina Beach, 1spec., UFPB/ECH.1583, 18.V.2007; Paraíba do Norte River Estuary, 1spec., UFPB/ ECH.89, 18.06.1980; 1spec., UFPB/ECH.1586. 13.VI.1983.

Type locality. Supposedly Senegal ('L' océan d'Afrique, les côtes du Senegal'), but probably West Indies (Clark and Downey 1992).

Description. Body flattened. Disk rounded. Nine long and narrow arms (rarely 7) (Fig. 4e, f). Paxillae on abactinal surface. Paxillae small, arranged irregularly, occupying center of disk and of arms. Paxillae of carinal regions rounded, with 1-4 central, short, rounded spinelets and 12-16 marginal spinelets disposed into two rows. Adradial paxillae quadrangular, disposed in regular longitudinal and tranversal rows, bearing 4-10 central, short, rounded spines (Fig. 4g). Inferomarginal plates with two short, conical and slightly compressed spines $(-2.20 \mathrm{~mm})$, the upper one being the smallest. Towards the mouth the inferomarginal plates are covered by short, lanceolate spines (Fig. 4f). Between these and the lateral margins slender spinelets occur. Adambulacral plates with four spines, two elongate, compressed and slightly curved adambulacral spines, and two elongate, flattened and lanceolate subambulacral spines (Fig. 4h). Oral spines long $(-2.59 \mathrm{~mm})$ and thin, forming a dense tuft of spines on the apex of jaw. Ocular plates well developed and grunuliform. Pedicellariae absent.

Colour. Dorsally bluish-grey or greenish-gray, with a strong dark line along the central region of the disk and of the arms. The actinal surface is white to cream-coloured.

Distribution. Florida, Cuba, Jamaica, Honduras, Nicaragua, Costa Rica, Panama, Venezuela and Brazil (Tommasi 1958, Clark 1982, Abreu-Pérez et al. 2005, Alvarado et al. 2008, del Valle García et al. 2008). In Brazil: PI, CE, PB, PE, AL, BA, 
RJ, SP, and SC (Rathbun 1879, Verrill 1915, Bernasconi 1943, Krau 1950, Tommasi 1958, 1970, Brito 1962, 1968, Lima-Verde 1969, Fernandes et al. 2002, Magalháes et al. 2005, Gondim et al. 2008, 2013, Gondim and Giacometti 2010, Xavier 2010, Miranda et al. 2012). This study provides the first record for the coast of Rio Grande do Norte. From 1 to $64 \mathrm{~m}$ in depth, being rare below $40 \mathrm{~m}$ (Clark and Downey 1992).

Remarks. Distinguished from the remaining species from Brazil by the presence of 7 to 9 arms. Luidia barbadensis Perrier, 1881, recorded for Bahamas, Florida, Gulf of Mexico and south Brazil is the closest species, but it may be distinguished from L. senegalensis for having 6 arms, inframarginal plates with two long and narrow spines, and the usual presence of pedicellariae. Walenkamp (1979) identified one specimen with 6 arms from Guyana as L. senegalensis. His identification was questioned for some time, but the presence of dark bands on the carinal region of the arms and disk and the depth of collection (32 $\mathrm{m}$, while the minimum known depth of $L$. barbadensis is $73 \mathrm{~m}$ ) confirm the validity of this identification (Clark and Downey 1992). Our observation of both juvenile (dd $\leq$ $15 \mathrm{~cm}$ ) and adult individuals permitted the conclusion that morphological characters do not vary during ontogeny. Thus forms with less than 7 arms or more than 9 arms (this later condition never having been observed in nature) must be the result of failures during metamorphosis (Hotchkiss 2000). As for the remaining Paxillosida, the structure of the paxillae represent a key taxonomic character for the identification of species.

Ecological notes. The species lives in environments of low hydrodynamism, in sediment containing sand, mud, or a combination of both of these (Hendler et al. 1995). It feeds mainly on molluscs, but also of other echinoderms such as sea-stars of the genus Astropecten and irregular echinoids, as well as ophiuroids, copepods, decapods, scaphopods, and polychaetes (Penchaszadeh and Lera 1983). Sometimes a small commensal crustacean (Minyoceras angustus Dana, 1852) is found in the interior of its ambulacrum. This crustacean was also observed in L. clathrata (Brito 1960). According to Hendler et al. (1995), individulas may attain 30-40 cm in disk diameter (dd), and attain sexual maturity when at $15 \mathrm{~cm}$ in diameter. Presently it is considered vulnerable to extinction along the Brazilian littoral. The main causes of population decline are its high succeptibility to the effects of pollution of the water column and the frequent accidental capture in trawling nets (Machado et al. 2008).

\section{Family Astropectinidae Gray, 1840}

Astropecten alligator Perrier, 1881

Figure 5a-d

Astropecten alligator Perrier, 1881: 30.

Astropecten nuttingi Verrill, 1915: 181, pl. 12, fig. 2e, pl. 21, figs 1-2.

Material examined. Paraíba: $7^{\circ} 01^{\prime} S ; 34^{\circ} 41^{\prime} 05^{\prime W}, 1$ spec., UFPB/ECH.881, 13.II.1981, $24 \mathrm{~m}$. 


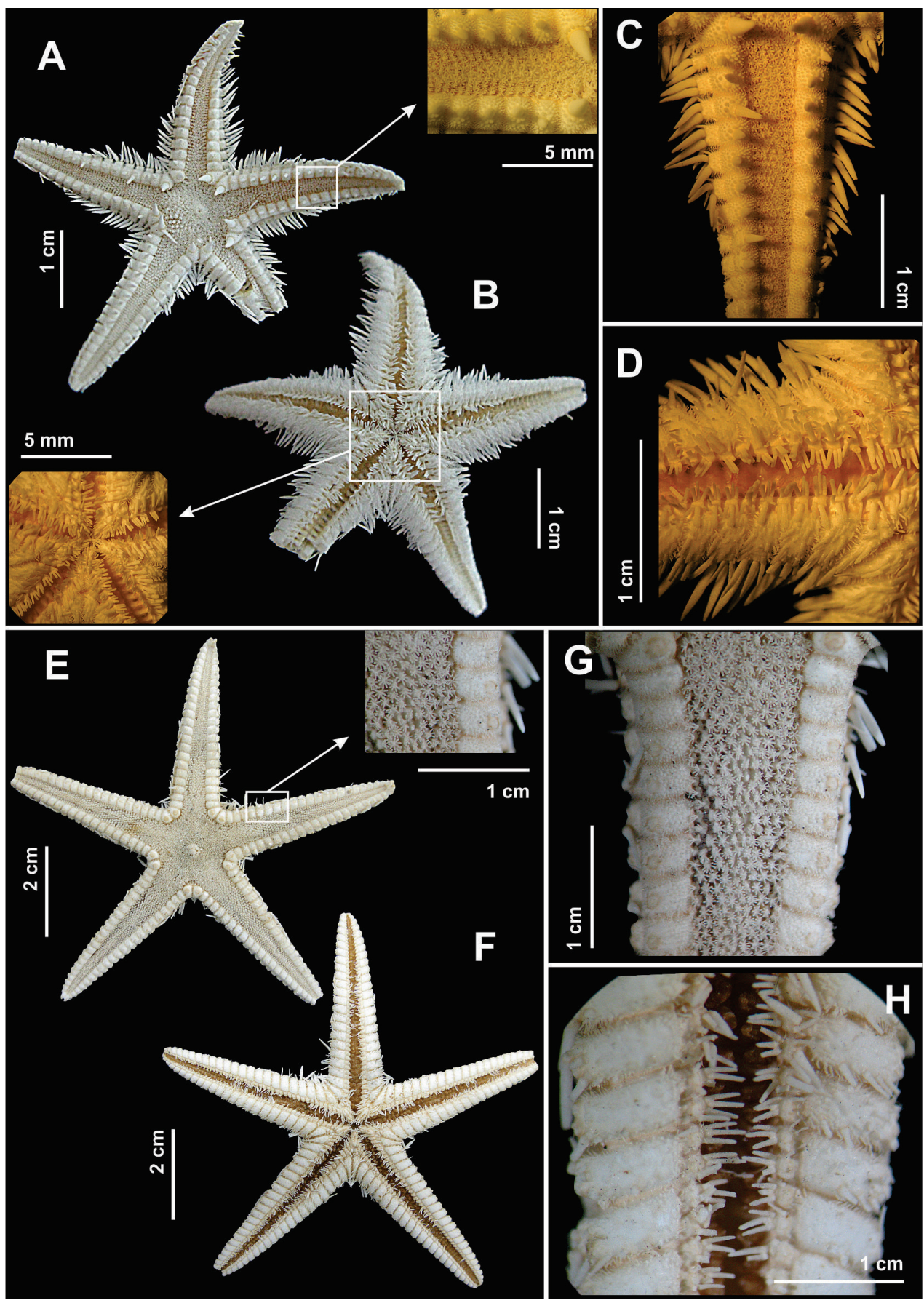

Figure 5. Some species of the family Astropectinidae recorded in northeastern Brazil. Astropecten alligator (A-D) A Abactinal view, in detail of the paxilla B Actinal view, in detail of mouth $\mathbf{C}$ Abactinal view of the arm $\mathbf{D}$ Actinal view of the arm; Astropecten cingulatus $(\mathbf{E}-\mathbf{H}) \mathbf{E}$ Abactinal view, in detail the paxilla $\mathbf{F}$ Actinal view $\mathbf{G}$ Abactinal view of the arm, and $\mathbf{H}$ Actinal view of the arm. 
Type locality. Alligator Reef, Florida Keys, Florida (Clark and Downey 1992).

Description. Body flattened dorso-ventrally. Disk small, with five long and narrow arms $(-4.93 \mathrm{~mm})$ (Fig. 5a, b). Epiproctal cone pronounced (this region of the disk and the surrounding areas are inflated) (Fig. 5a). Abactinal surface flat and covered by small paxillae disposed in regular rows (Fig. 5a). Paxillae with a central spinelet and 8-10 (usually 9) thick, marginal spinelets with blunts extremities. Superomarginal plates short $(-1.14 \mathrm{~mm})$ and narrow $(-1.59 \mathrm{~mm})$, covered by short and blunt spinelets, giving a granulose appearance to animals. Each of these plates has an elongate, conical and pointed spine (Fig. 5a, c), which has the same length from the interbrachial area to the extremity of each arm. Inferomarginal plates with two long, flattened and pointed spines, placed in parallel to each other. These plates are also covered by short and narrow spinelets. Towards the mouth the inferomarginal plates are covered by many flattened and pointed spines, which become elongated at the margins. Adambulacral plates with three long, flattened adambulacral spines, placed in parallel to each other, the median one being slightly longer than the other two (Fig. 5d). There are three to four long and flattened subambulacral spines, the median of which is longer and wider than the other two.

Colour. Reddish-brown dorsally, with conspicuous dark bands along the center of each arm (Clark and Downey 1992), or uniformly orange-red.

Distribution. North Carolina, the Bahamas, Florida, Honduras, Nicaragua Colombia, and Brazil (Verrill 1915, Gray et al. 1968, Clark and Downey 1992, Benavides-Serrato et al. 2005, 2011, Alvarado et al. 2008). In Brazil: Benavides-Serrato et al. (2005) cite its occurrence in the north of Brazil. This study expands the distribution southward to the State of Paraíba, being the first reference for the northeast region of Brazil. From 22 to $576 \mathrm{~m}$ in depth (Benavides-Serrato et al. 2011), most frequent between 22 and $114 \mathrm{~m}$ (Clark and Downey 1992).

Remarks. Astropecten alligator difers from the remaining species in the genus recorded for Brazil for presenting a single, elongate, erect conical spine on all the superomarginal plates. This character is present in both juvenile and adult individuals ( $\mathrm{dd}=$ $41.0 \mathrm{~mm}$ ). For a long time it was believed that Perrier (1881) had described A. alligator based on a juvenile specimen and the recognition of this species remained uncertain. Clark and Downey (1992) analised the type material of $A$. alligator. They were able to validate the species and consider Astropecten nuttingi Verrill, 1915 a junior synonym of this taxon. In a molecular phylogenetic analysis of Astropecten, Zulliger and Lessios (2010) concluded that $A$. alligator and $A$. americanus probably belong to the same species and that the species needs to be extensively revised.

Ecological notes. Usually inhabits muddy environments, but may also be found associated to communities of azooxanthelate corals (Benavides-Serrato et al. 2011). It is common along the coast of Florida (Clark and Downey 1992), but for a long time it has been erroneously cited there as Astropecten nuttingi. In other areas A. alligator is a rare species, being little cited in the literature. 


\section{Astropecten articulatus (Say, 1825)}

Asterias articulata Say, 1825: 144.

Astropecten dubius Gray, 1840: 182.

Asterias aranciaca Gould, 1841: 349 (non Asterias aranciaca Linnaeus, 1758).

Astropecten articulates Müller \& Troschel, 1842: 72. Tommasi 1970: 6, fig. 17. Tommasi

et al. 1988: 5. Manso 1989: 357.

Astropecten buschi Müller \& Troschel, 1843 (a variety of Astropecten articulatus (Say,

1825) according to Doderlein (1917)).

Astropecten articulatus dubius Verrill, 1915: 165.

Astropecten articulatus var. valenciennesi A.H.Clark, 1939: 442.

Astropecten articulatus duplicatus Zoppi de Roa, 1967: 277, fig. 6. (non Astropecten duplicatus Gray, 1840).

Material examined. Caraguatatuba, São Paulo, 1 spec., MZUSP484, 16.X.2001, 19m.

Type locality. Florida (Clark and Downey 1992).

Description. Body pentagonal, flattened dorso-ventrally. Five long and narrow arms (length of arm corresponds to approximately four times its width), which become gradually narrow towards tips. Abactinal surface with paxillae. Paxillae disposed regularly, carenals smaller than adradials. 1-6 short, thick and blunt paxillar spines in center, $10-16$ in margins. Supermarginal plates granulose, with a large spine $(-1.54$ $\mathrm{mm}$ ) positioned internally on the interbrachial plates. Some distal supermarginal plates have a short spine positioned more externally. Inferomarginal plates with two elongate, flattened and pointed marginal spines, positioned horizontally. Small oral spine. Three adambulacral spines divergent, the median one being the largest.

Colour. Dorsally dark blue or purple in paxillar region. Superomarginal plates white or orange. Oral surface white of beige (Hendler et al. 1995; Benavides-Serrato et al. 2011).

Distribution. North Carolina, Florida, the Bahamas, Mexico, Cuba, Puerto Rico, Dominican Republic, Panama, Colombia, Venezuela, Brazil, and Uruguay (Tommasi 1970, Clark and Downey 1992, Hendler et al. 1995, Alvarado 2011). In Brazil: PI, CE, RJ, SP, and RS (Lima-Verde 1969, Netto 2006). From 0 to $550 \mathrm{~m}$ in depth, being most common between 5 and 20 m (Clark and Downey 1992, Hendler et al. 1995).

Remarks. Astropecten articulatus differs from the congeneric $A$. cingulatus for having a spine or tubercule on the distal supermarginal plates, two flat spines on each inferomarginal plate and subambulacral spines larger that the adambulacral spines. The original description of $A$. articulatus Say (1825) is excelent, but the emphasis given by this author on the presence of spines and tubercules resulted in some uncertainty regarding the validity of $A$. duplicatus (Gray, 1840) (Clark and Downey 1992). According to Clark and Courtman-Stock (1976) and Clark and Downey (1992) the confidence in the presence of spines on the superomarginal plates as a specific criterium is doubtful. As in other species of the genus, A. articulatus presents a series of morphological variations. Verrill (1915) provides a good discussion of these variations, and 
stresses the differences found between juvenile and adult individuals. We have only been able to examine a single juvenile specimen, which nevertheless presented all the diagnostic characters of the adults.

Ecological notes. Inhabits sandy environments. According to Benavides-Serrato et al. (2011) and Hendler et al. (1995), this species is common offshore over continental shelf, being particularly abundant in North Carolina. Astropecten articulatus is a voracious and non-selective predator (Hendler et al. 1995). Wells et al. (1961) recorded 91 food items for 124 specimens collected in North Carolina, gastropods, bivalves, and scaphopods being the most importante items. Small crustaceans, juveniles of Mellita sp. and $A$. articulatus itself were also recorded as food items for the species, although in a lower level of importance (Hendler et al. 1995).

\section{Astropecten brasiliensis Müller \& Troschel, 1842}

Astropecten brasiliensis Müller \& Troschel, 1842: 68. Tommasi et al. 1988: 5. Manso 1989: 357. Fernandes et al. 2002: 422. Netto 2006: 25-26, pl. 2a, fig. 16a. Ventura et al. 2007: 230. Machado et al. 2008: 350. Lima and Fernandes 2009: 58.

Xavier 2010: 75. Miranda et al. 2012: 143, 144.

Astropecten braziliensis Rathbun, 1879: 150. Tommasi 1970: 6.

Astropecten brasiliensis riensis Döderlein, 1917: 84.

Astropecten brasiliensis armatus Jonh, 1948: 503.

Astropecten armatus brasiliensis Tortonese, 1956: 329. Tommasi 1958: 12-13, pl. 2, fig.

3; 1970: 7, fig. 19. Brito 1962: 3; 1968: 7-8, pl. 4, fig. 3. Lima-Verde 1969: 10.

Carrera-Rodrigues and Tommasi 1977: 81-83. Magalhães et al. 2005: 63.

Astropecten brasiliensis brasiliensis Döderlein, 1917: 83.

Astropecten armatus riensis Tommasi, 1958: 13-14, pr. 2, fig. 4. Brito 1962: 3; 1968 :

8, pl. 4, fig. 2.

Astropecten riensis Tommasi, 1970: 7. Carrera-Rodrigues and Tommasi 1977: 89. Tommasi and Aron 1988: 3. Tommasi et al. 1988: 5.

Material examined. Ceará: Fortaleza, Mucuripe, 1 spec., MNRJ285, 1945. Rio Grande do Norte: Areia Branca, Ponta do Mel, 1 spec., UFPB/ECH.1919, 23.VI.182. Bahia: Salvador, 2 spec., UFBA00132, 01.III.2000.

Type locality. São Sebastião Island, São Paulo, Brazil (Clark and Downey 1992).

Description. Disk small with long, slender, dorsally flattened arms $(-12.44 \mathrm{~mm})$. Abactinal surface densely covered by overlapping and irregularly arranged paxillae. Paxillae with 26-30 long, blunt spinelets, the central ones sometimes shorter and more rounded than the marginal ones. Carinal paxillae larger than the adradial ones. Superomarginal plates longer $(-5.7 \mathrm{~mm})$ than wide $(\sim 1.19 \mathrm{~mm})$, covered by short, apically rounded spinelets (giving them a granulose aspect), and having two large spines (rarely one). Inferomarginal plates with two long and flattened spines positioned vertically and forming a marginal fringe, the most ventral one being larger than the dorsal one. 
Adambulacral plates with three ambulacral spines, the inner one being slightly longer than the other two. Without pedicellariae.

Colour. According to Bernasconi (1957), live animals have an intense violet colour with the spines of the marginal fringe yellowish or pinkish. Actinal surface light salmon colour. When dry specimens may be light pink or whitish.

Distribution. Honduras, Panama, Suriname, Brazil, Uruguay, and Argentina (Mar del Plata) (Tommasi 1958, 1970, Clark and Downey 1992, Alvarado et al. 2008, Ventura et al. 2007). In Brazil: CE, PE, AL, BA, RJ, SP, SC, and RS, incluing the islands of Fernando de Noronha and Trindade (Rathbun 1879, Verrill 1915, Tommasi 1958, 1970, Walenkamp 1976, Brito 1962, Lima-Verde 1969, Fernandes et al. 2002, Miranda et al. 2012). In this paper we establish the first record for Rio Grande do Norte. From 7 to $45 \mathrm{~m}$ in depth (Ventura et al. 2007).

Remarks. This species differs from the remaining species of the genus known from the Brazilian coast for presenting paxillary spinelets and spines of the marginal fringe long and thin and for having up to two spines on the supermarginal plates. The vast synonymy presented by Astropecten brasiliensis evidences the plasticity of some of its characters, such as the number of spines on the superomarginal plates. This character, together with the shape of the marginal spines and paxillae spinelets formed the basis for the establishment of the five known subspecies. Döderlein (1917) considered $A$. armatus Gray, 1840 and $A$. erinaceus Gray, 1840 subspecies of $A$. brasiliensis on the basis of differences in the adambulacral and superomarginal spines. Boone (1933), Clark (1940) and John (1948) disagreed with Döderlein (1917) and considered the three species not to be different, stating that the characters proposed to diagnose the species were not significant. Walenkamp (1976) listed a series of variations observed in specimens from Surinam and established $A$. brasiliensis and $A$. riensis as distinct species. Bernasconi (1957), Brito (1968) and Tommasi $(1958,1970)$ adopted the subspecies proposed by Müller and Troschel (1842) and Döderlein (1917) for Brazilian material. Clark and Downey (1992), analysing the neotype of the species, concluded that $A$. brasiliensis and $A$. armatus are distinct, while $A$. riensis is a synonym of the first. Furthermore, he considered all the described subspecies to be synonyms. We agree with the proposal of Clark and Downey (1992) and include the subspecies (A. brasiliensis riensis, $A$. brasiliensis armatus, $A$. brasiliensis brasiliensis and $A$. armatus riensis) and $A$. riensis as synonyms of $A$. brasiliensis. The specimen examined in this study was broken, but its taxonomic characters were observable, except for the loss of the superomarginal spines. Scars of these spines remained on the plates, however, and we were able to establish that two spines occurred per plate, characterizing an adult individual.

Ecological notes. As a rule burrowed in sand substrates, where it is a generalist predator, feeding on a variety of organisms from the benthic endofauna, such as bivalves, gastropods, crustaceans, echinoderms, and polychaetes (Ventura et al. 2007). As all species inhabiting soft sediments, Astropecten brasiliensis is suffering the impact of excessive collecting, being captured in bottom trawling nets and frequently do not resist the damage inflicted by these fishing efforts (Machado et al. 2008). Presently the species is considered to be vulnerable to extinction along the Brazilian coast. 


\section{Astropecten cingulatus Sladen, 1833}

Figure 5e-h

Astropecten cingulatus Sladen, 1883: 266. Brito 1962: 3; 1968: 9, pl. 4, fig. 4. Tommasi 1970: 5, fig. 16; 1985: 3. Carrera-Rodrigues and Tommasi 1977: 84-86. Tommasi and Aron 1987: 3. Manso 1989: 357. Tommasi et al. 1988: 5. Ventura et al. 2007: 231. Xavier 2010: 75.

Astropecten mesactus Studer, 1884: 46.

Astropecten jarli Madsen, 1950: 181.

Material examined. Rio de Janeiro: Cabo Frio, 1 spec., MNRJ1853, 18.VI.1997.

Type locality. Pernambuco, Brazil (Clark and Downey 1992).

Description. Body pentagonal, flattened dorso-ventrally. Five long $(-37.70 \mathrm{~mm})$ and narrow $(-9.56 \mathrm{~mm})$ arms (length of arm corresponds to approximately four times its width) (Fig. 5e). Madreporite oval $(-1.52 \mathrm{~mm})$ and marginal. Epiproctal cone pronounced. Paxillae small and granulose, with 1-4 central spinelets and 9-12 marginal spinelets. Paxillar spinelets granulose (Fig. 5e). Superomarginal plates granulose (Fig. $5 \mathrm{~g})$. Two fringes of marginal spines aligned horizontally. First row of spines of inferomarginal plates with three marginal spines, disposed in parallel to each other, two being of the same length and one shorter. Second row with four elongate and slightly flattened spines, three of which are subequal in length and one much shorter. Oral spines short, forming a bundle at the apex of the jaw (Fig. 5f). Adambulacral plates with 3-4 divergent spines, the median one being the largest (Fig. 5h). Subambulacral spines forming a bundle of elongate and slightly flattened (lanceolate) spines. Pedicellariae rarely present.

Colour. According to Benavides-Serrato et al. (2011) and Bernasconi (1957), the species has the abactinal surface red or orange-red and the actinal surface white. Ventura et al. (2007) recorded a cream-colour on the dorsal surface and white on the oral surface in Brazilian specimens.

Distribution. North Carolina, the Bahamas, Gulf of Mexico, Mexico, Nicaragua, Costa Rica, Panama, Colombia, Brazil, Uruguay, Argentina, and Africa (Tommasi 1970, Carrera-Rodríguez and Tommasi 1977, Clark and Downey 1992, Ventura et al. 2007, Alvarado et al. 2008). In Brazil: PE, RJ, SP, and SC, including the submarine banks and mountain ranges Vitória-Trindade and Vitória Island (SP) (Brito 1962, Tommasi 1970, 1985, Tommasi and Aron 1987, Manso 1989, Xavier 2010). Intertidal to $1350 \mathrm{~m}$ in depth (Clark and Downey 1992), being most frequent between 51 and $129 \mathrm{~m}$ (Carrera-Rodríguez and Tommasi 1977).

Remarks. Astropecten cingulatus differs from its closest species, A. articulatus, for having three rounded spines on each inferomarginal plate, and for having subambulacral spines that are smaller than the adambulacral spines and rounded. Bernasconi (1957) stresses a few morphological variations observed in specimens from Uruguay and Argentina. Among these are the aspect of the superomarginal plates, which do not have large spines, or then there are only a few small, granuliform spines on the first plates. According to Ventura et al. (2007) the specimens collected along the Brazilian 
coast have short arms, in contrast to the indication in the original diagnosis. The single individual we examined, on the other hand, corresponds to that indicated in the literature (lenght about four time its width).

Ecological notes. This species lives on sandy or muddy bottoms of the littoral region up to depths of $50 \mathrm{~m}$ (Tommasi 1970, Machado et al. 2008). It feeds mainly on gastropods, bivalves, crustaceans, and cirripeds (Ventura et al. 2007). Astropecten cingulatus, and other species of the genus, are frequently captured in trawling nets and the species is presently included among those vulnerable to extinction in Brazil (Machado et al. 2008). According to Brito (1962), this species is abundant along the coast of Pernambuco, but no other works conducted in this state confirm this observation.

\section{Astropecten marginatus Gray, 1840}

Figures $6 \mathrm{a}-\mathrm{e}, 12 \mathrm{~b}$

Astropecten marginatus Gray, 1840: 181. Tommasi 1958: 14, pl. 2, fig. 5; 1970: 5, fig. 15.

Brito 1962: 3; 1968: 7, pl. 4, fig. 1. Lima-Verde 1969: 11. Carrera-Rodrigues and

Tommasi 1977: 88-89. Tommasi et al. 1988: 5. Nomura and Fausto Filho 1966:

19. Gondim et al. 2008: 155. Lima and Fernandes 2009: 58. Xavier 2010: 75. Astropecten ciliatus Grube, 1857: 340. Astropecten richardi Gary, 1840: 181. Astropecten orans Sluiter, 1895: 54.

Material examined. Rio Grande do Norte: Areia Branca, Ponta do Mel, 2 spec., UFPB/ECH.1842, 23.VI.1982. Paraíba: Cabedelo, Miramar Beach, 1 spec., UFPB/ ECH.1840, 03.II.1983; Joāo Pessoa, 77'23,3"S; 3448'27,9"W, 1 spec., UFPB/ ECH.1839, 14.IX.1980; João Pessoa, Tambaú Beach, 1spec., UFPB/ECH.864, 03.X.2007. Pernambuco: Goiana, Catuama, UFPB/ECH.1427, 1 spec., 31.X.1982.

Type locality. Unknown (Clark and Downey 1992).

Description. Body flattened. Five broad, triangular arms (Fig. 6a, b). Abactinal surface covered by paxillae arranged in regular transversal rows. Circular madreporite positioned marginally in one of the abactinal intermediate areas. Carinal paxillae slightly smaller than the adradials (Fig. 6d). Paxillae small with 6-8 central spinelets and 12 marginal spinelets, all short and blunts. Superomarginal plates granulose, broader $(-3.89 \mathrm{~mm})$ than long $(-2.00 \mathrm{~mm})$ (Fig. 6c, d). Inferomarginal plates granulose, with two thick, blunt, parallel spines of similar length $(-3.92 \mathrm{~mm})$ and one small spine positioned laterally in relation to the other two. These spines form a well defined marginal bundle. Actinal surface with inferomarginal plates partially naked, having two series of marginal spines positioned laterally and one other marginal series with four thin, elongate, and flattened spines $(\sim 1.66 \mathrm{~mm})$, located behind the aboral marginal row of spines (Fig. 6e). Adambulacral plates with a series of small spines on the proximal face and three long, narrow, and flattened adambulacral spines, the median 


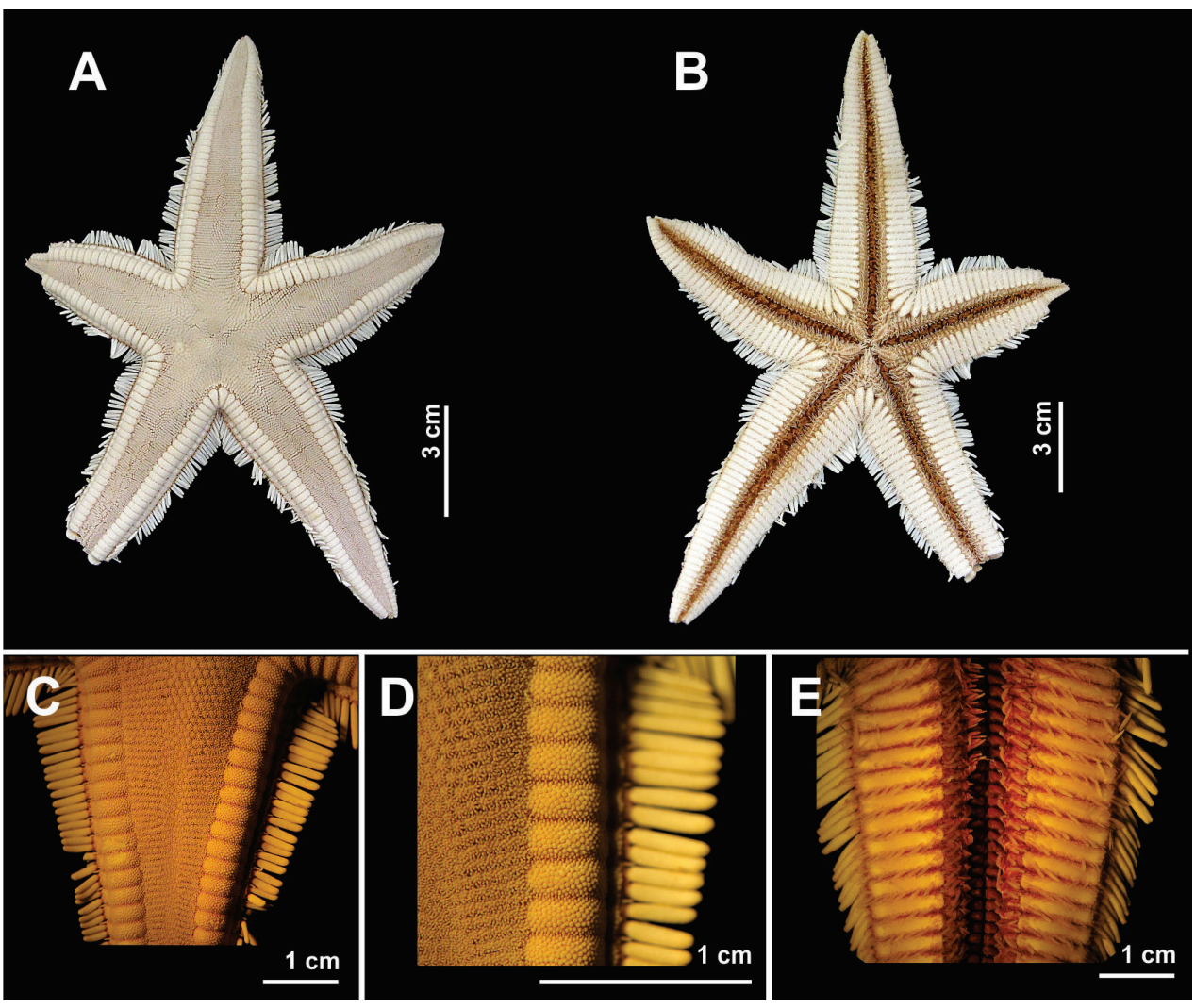

Figure 6. Some species of the family Astropectinidae recorded in northeastern Brazil. Astropecten marginatus (A-E) A Abactinal view B Actinal view $\mathbf{C}$ Abactinal view of the arm $\mathbf{D}$ Detail of the superomarginal plate, and $\mathbf{E}$ Actinal view of the arm.

of which is longest and widest. Six elongate, narrow, and pointed oral spines $(-1.67$ $\mathrm{mm})$. Ocular plate small and bilobed.

Colour. Dorsally either blue with white margins (Clark and Downey 1992) or uniformly orange-coloured (Benavides-Serrato et al. 2011). Most specimens collected in northeastern Brazil vary from cream-coloured to grayish. Dried specimens become white.

Distribution. Costa Rica, Puerto Rico, Colombia, Venezuela, Guyana, and Brazil (Tommasi 1958, Clark and Downey 1992, Hendler et al. 1995, Alvarado et al. 2008, Benavides-Serrato et al. 2005, 2011). In Brazil: CE, PB, PE, RJ, SP, SC, and RS (Bernasconi 1955, Brito 1962, Lima-Verde 1969, Netto 2006, Gondim et al. 2008, Lima and Fernandes 2009, Xavier 2010). This is the first record for the littoral of Rio Grande do Norte. From 1 to 130 m in depth (Clark and Downey 1992).

Remarks. Astropecten marginatus differs from the remaining species of the genus known from Brazil for having large, triangular arms and two long, thick and blunt spines on each inferomarginal plate. Unlike other species of Astropecten, A. marginatus 
shows little morphological variation in characters considered of taxonomic interest (Walenkamp 1976). We observed both juveniles $(\mathrm{R}=11.73 \mathrm{~mm})$ and adults $(\mathrm{R}=$ $81.41 \mathrm{~mm})$.

Ecological notes. This species lives in substrates containing sand or sand with mud (Ortega et al. 2010). As most species of the genus, it is an active predator with a generalist food diet (Ortega et al. 2010). This is one of the most common species in northeastern Brazil, being abundant below 2-4 m (Benavides-Serrato et al. 2011). Together with other species in the genus, populations of $A$. marginatus suffer great collecting pressures from bottom trawling fishing nets. Presently it is included among the Brazilian species vulnerable to extinction (Machado et al. 2008).

\section{Order Valvatida Perrier, 1884 \\ Family Asterinidae Gray, 1840}

\section{Asterinides folium (Lütken, 1860)}

Figure 7a-e

Asterina minuta Gray, 1840: 289.

Asteriscus folium Lütken, 1860: 60-61.

Asterina folium A. Agassiz, 1877: 106, pl. 14, figs 7-9.

Asterinides folium Verrill, 1913: 479; Brito 1962: 3; 1968: 17, pl. 7, figs 2-3; 1971:

262. Tommasi 1970: 15, fig. 38. Oliveira et al. 2010: 3, fig. 2 a.

Material examined. Paraíba: 06 $599^{\prime} S$; $34^{\circ} 47^{\prime} \mathrm{W}, 1$ spec., UFPB/ECH.572, 07.III.2006, 10m. Bahia: Camaçari, Guarajuba, Busca Vida Beach, 1spec., UFBA00685, 01.II.2006; 2spec., UFBA00983, I.2010, 23m; 1spec., UFBA01163, VII.2010, 25m; 2spec., UFBA01107, I.2010, 23m; Salvador, Todos os Santos Bay, 1spec., UFBA01107, 05.IV. 1997, 12m; Salvador: Itapuâ, $12^{\circ} 57^{\prime} 28^{\prime \prime S}$; 38²1'22"W, 1spec., UFBA00528, 19.XI.2007, $1 \mathrm{~m}$.

Type locality. Saint Thomas, Virgin Islands (O'Loughlin 2002).

Description. Body inflated, pentagonal (Fig. 7a, b). Five short arms (some specimens may have 4-6 arms). Abactinal plates imbricated, decreasing in size towards the margin of the body, with 2-4 short, hyaline, divergent spines, which have the extremity trifurcate (Fig. 7c). Between each of these plates there is a papula (Fig. 7c). Anus located in the center of the abactinal surface. Superomarginal plates similar to the remaining abactinal plates, but with more numerous and slightly longer spines, forming a dense bundle (Fig. 7a). Papulae restricted to the abactinal surface. Actinal plates similar to the abactinal plates, but a little bigger and longer, having 1-3 divergent spines, also similar to the dorsal ones, but slightly longer (Fig. 7b). Inferomarginal plates similar to the remaining actinal plates. Adambulacral plates with three thin, vitreous, elongate spines $(-0.035 \mathrm{~mm})$, having the tips trifurcate (Fig. $7 \mathrm{~d})$. Six thin, vitreous, elongate oral spines $(-0.43 \mathrm{~mm})$ (Fig. $7 \mathrm{e})$. 


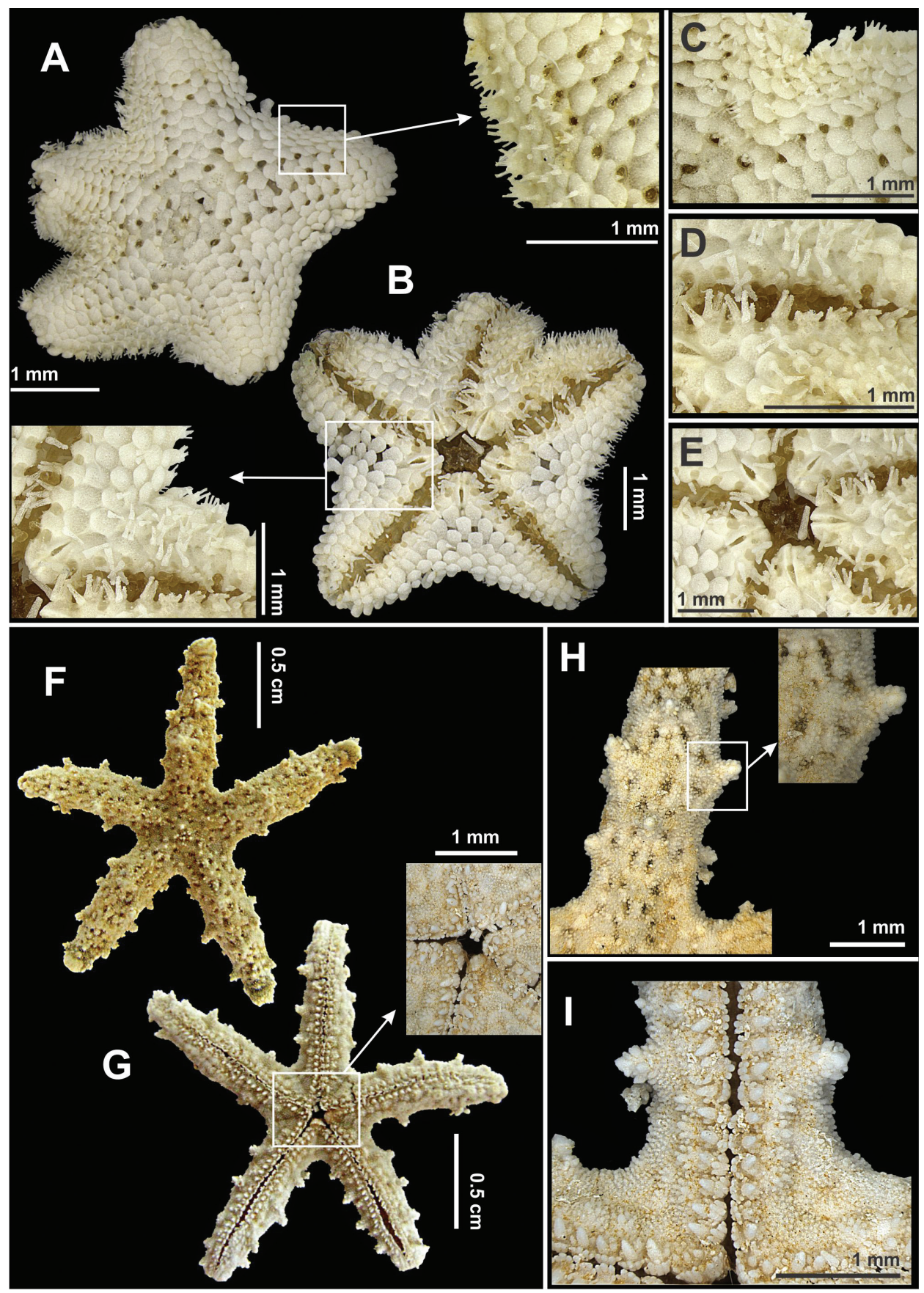

Figure 7. Some species of the order Valvatida recorded in northeastern Brazil. Asterinides folium (A-E) A Abactinal view, in detail the superomarginal plates B Actinal view, in detail actinal internidate area C Detail the abactinal intermediate are D Actinal view of the arm E Detail of the mouth; Mithrodia clavigera $(\mathbf{F}-\mathbf{I}) \mathbf{F}$ Abactinal view $\mathbf{G}$ Actinal view, in detail the mouth $\mathbf{H}$ Abactinal view of the arm, in detail a spine, and I Actinal view of the arm. 
Colour. Juvenile specimens vary from white to cream-coloured, larger juveniles are yellow to reddish, while adults are blue or greenish-blue (Hendler et al. 1995). Brito (1968) recorded a dark grayish-blue for 25 specimens from Trindade Island (ES).

Distribution. Bermudas, Florida, Bahamas, Belize, Panama, and Brazil (Verrill 1915, Clark and Downey 1992, Hendler et al. 1995, Alvarado et al. 2008, BenavidesSerrato et al. 2011). In Brazil: BA, RJ, and Trindade Island (Brito 1962, 1968, 1971, Oliveira et al. 2010). In the presente study we record for the first time its presence in the State of Paraíba. Intertidal to $15 \mathrm{~m}$ in depth (Hendler et al. 1995).

Remarks. Only two species of the genus Asterinides are known from the Atlantic Ocean, A. folium and A. hartmeyeri (Döderlein, 1910). The first is recorded for Bermudas and southern Brazil and the second only for the Caribbean region. According to Clark and Downey (1992) these species are partially sympatric, and for this reason have previously easily been confused with each other. In a revision of family Asterinidae based on molecular and morphological data, O'Loughlin and Waters (2004) transferred $A$. folium and $A$. hartmeyeri from the genus Asterina to the genus Asterinides, remarking on the morphological similarities between these two species. Asterinides folium differs from $A$. hartmeyeri for having bigger papular pores, 6 to 7 series of actinal plates and abactinal plates arranged into two rows. A broad discussion of the main differences between these two species is given by Clark and Downey (1992). According to Hendler et al. (1995), this species rarely reaches $2.5 \mathrm{~cm}$ in diameter. Specimens examined in this study had a larger ray $(R$, maximum of $7.76 \mathrm{~mm}$ ) and differed from those described by Hendler (op cit.) for not having narrow radial areas inflated, having instead the abactinal surface completely inflated.

Ecological notes. This species lives in association with coral reefs, being found particularly under rocks or corals of the reef flat (Hendler et al. 1995). The specimen from Paraíba recorded in this study was found associated with rhodolite beds at $10 \mathrm{~m}$ depth. Although the species is reported from several localities, is has never been found in large numbers (Hendler et al. 1995, Benavides-Serrato et al. 2011). Only Brito (1971) observed this species to be relatively abundant mainly under rocks at Trindade Island.

\section{Family Mithrodiidae Viguier, 1878}

Mithrodia clavigera (Lamarck, 1816)

Figure $7 f-i$

Asterias clavigera Lamarck, 1816: 562.

Mithrodia clavigera Verrill, 1870: 289.

Mithrodia spinulosa Gray, 1840: 288.

Ophidiaster echinulatus Müller \& Troschel, 1842: 32.

Echinaster echinulatus von Martens, 1866: 59. 
Mithrodia clavigera Perrier, 1875: 378.

Mithrodia victoriae Bell, 1882: 123, pl. 6, fig. 2. Brito 1962: 3; 1968: 16. Tommasi 1970: 19, fig. 55.

Material examined. Paraíba: 704'S; 34²1'W, 1 spec., UFPB.ECH.880, 17.II.1981, $26 \mathrm{~m}$.

Type locality. Unknown (Clark and Downey 1992).

Description. Disk small (Fig. 7f). Five cylindrical and narrow arms $(-2.52 \mathrm{~mm})$ (Fig. 7f, g). Abactinal and actinal surfaces granulose (Fig. 7h). Skeleton formed by polygonal primary plates (usually hexagonal) that are widely spaced and united by secondary plates of rectangular shape, forming a reticulum. Some carinal and adradial plates with a long, narrow, and blunt spine $(-0.77 \mathrm{~mm})$. Papula large and single, found between the abactinal plates. Papulae restricted to abactinal surface. Granules covering body and spines small and with spinous tip. Granules from base of spines larger than at other localities. One conical and elongate subambulacral spine $(\sim 0.32 \mathrm{~mm})$, forming a well defined row at base of ambulacral groove (Fig. 7i). Four slightly flattened adambulacral spines, the median ones being the largest. Eight short and rectangular oral spines, of which the median ones are largest (Fig. $7 \mathrm{~g}$ ).

Colour. Arms banded with dark brown or red lines, unusually green (Clark and Downey 1992). Specimens preserved in alcohol become uniformly white.

Distribution. Mexico, Cuba, Nicaragua, Brazil, Indo-Pacific (except Hawaii) (Hayashi 1940, Abreu-Pérez et al. 2005, Alvarado et al. 2008). In Brazil: ES (Vitória Banks) (Brito 1968, Clark and Downey 1992). In this study we provide the first record for northeastern Brazil. From 24 to $71 \mathrm{~m}$ in depth (Clark and Downey 1992).

Remarks. Mithrodia clavigera is the only species of the family Mithrodiidae recorded for the Western Atlantic. For some time, two species were considered present: $M$. clavigera and $M$. victoriae. The later species was described by Bell (1882), based on two small specimens from submerged banks of Vitória (Victoria Bank) (Espírito Santo, Brazil). Since its description the validity of $M$. victoriae was questioned, and the distinction between these two species was discussed by Engel et al. (1948) and Pope and Rowe (1977). These authors concluded that the species should be synonymized but, due to the lack of material, this action was not formally carried out. Clark and Downey (1992) analised a large number of individuals of several sizes and agreed with the observations of Engel et al. (op. cit.) and Pope and Rowe (op. cit.), considering the two species to be synonyms. The individual we analised is juvenile $(\mathrm{R}=9.80 \mathrm{~mm})$ and corresponds to the characterization of juvenile specimens by Engel et al. (1948). These authors provide details on the aspect of the pedicellariae of Mithrodia clavigera, but pedicellariae were not found in our specimen.

Ecological notes. This species lives on hard substrates covered by incrusting organisms and in reef gravel (Abreu-Pérez et al. 2005). For Paraíba it was recorded associated with rhodolith banks. According to Guille et al. (1986) this species is more active during the night. 


\section{Family Oreasteridae Fisher, 1911}

\section{Oreaster reticulatus (Linnaeus, 1758)}

Figure 8a-g, 12c

Asterias gigas Linnaeus, 1753: 114.

Asterias reticulata Linnaeus, 1758: 661.

Pentaceros reticulatus Gray, 1840: 276.

Oreaster reticulatus Linnaeus, 1758. Tommasi 1958: 16-17, pl. 3, fig. 2; 1970: 10-11, fig.

31. Brito 1962: 3; 1968: 5-6, pl. 2, figs 1-3. Lima-Verde 1969: 11. Fernandes et al. 2002: 422. Magalhães et al. 2005: 63. Ventura et al. 2007: 238. Manso et al. 2008: 185,

fig. 8c, d, e. Xavier 2010: 75. Alves et al. 2010: 757. Miranda et al. 2012: 143, 144.

Oreaster aculeatus Müller \& Troschel, 1842: 50.

Oreaster lapidarius Grube, 1857: 342.

Oreaster tuberosus Möbius, 1859: 6.

Oreaster gigas Lütken, 1860: 64-75.

Oreaster reticulatus var. bermudensis H.L. Clark, 1942: 372, figs 1-2.

Material examined. Ceará: off Fortaleza, 1spec., UFPB/ECH.1255, Geomar XXIV, V.1985. Paraíba: 1spec., UFPB/ECH.1579, 26.X.1980; Cabedelo, Farol de Cabedelo Reef, UFPB/ECH.1254, 22.I.1981, 26m; 1spec., UFPB/ECH.1588, 26.X.1980;

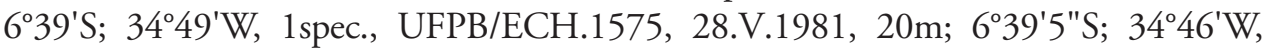
1spec., UFPB/ECH.1429, 1spec., 29.V.1981, 35m; 6³9’05"S; 3449"W, 1 spec., UFPB/ECH.1251, 28.V.1981, 20m; 6³9'05"S; 34²9'W, 1spec., UFPB/ECH.1578, 28.V.1981, 20m; 650'S; 34²77'W, 1spec., UFPB/ECH.1253, 11.V.1981, 18m; 652'S;

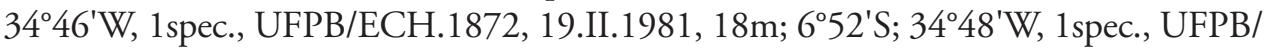
ECH.1590, 04.II.1981, 10m; 652'S; 3449'W, 1spec., UFPB/ECH.1593, 04.II.1981,

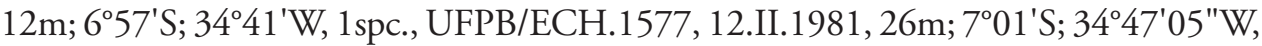
2spec., UFPB/ECH.1252, 02.V.1981, 11m; $7^{\circ} 04^{\prime} \mathrm{S} ; 34^{\circ} 41^{\prime} \mathrm{W}, 2$ spec., UFPB/ ECH.1576, 17.II.1981, 22m; 0704'24,4"S; 03447'49"W, 1spec., UFPB/ECH.1871, 24.VI.2005, 6m; $7^{\circ} 07^{\prime}$ S; $34^{\circ} 47^{\prime} \mathrm{W}, 1$ spec., UFPB/ECH.1430, 05.II.1981, 10m; $7^{\circ} 10^{\prime} \mathrm{S}$; $34^{\circ} 38^{\prime} \mathrm{W}, 1$ spec., UFPB/ECH.1873, 26.03.1981, 25m; $7^{\circ} 13^{\prime} \mathrm{S} ; 34^{\circ} 42^{\prime} \mathrm{W}, 1$ spec., UFPB/ ECH.1574, 27.III.1981, 10m; 7³4'S; 34³9'W, 1spec., UFPB/ECH.1594, 1spec., 7³4'S; 34³9'W, Paraíba, 22.I.1981, 26m. Pernambuco: Itamaracá Island, 4spec., UFPB/ECH.1581, VIII.1980, 20m; Suape Beach, 1spec., UFPB/ECH.1580, I.1980.

Type locality. 'Las Antillas Occidentales' or 'Spanish West Indies' (Clark and Downey 1992).

Description. Body pentagonal. Disk high, inflated, concave on actinal side (Fig. 8a, b). Five short arms (Fig. 8a). Abactinal plates with one thick, short, blunt spine $(-2.43$ $\mathrm{mm}$ ). Among these plates there occur papular areas, which are covered by small granules and bivalve pedicellariae (Fig. 8c). These granules cover the entire body, including the bases of the spines. Superomarginal plates with one short, thick and blunt spine $(-3.38$ $\mathrm{mm}$ ), determining the margin of the body. Inferomarginal plates similar to superomarginal plates, with one or two small and thick spines. Papular areas restricted to abactinal 


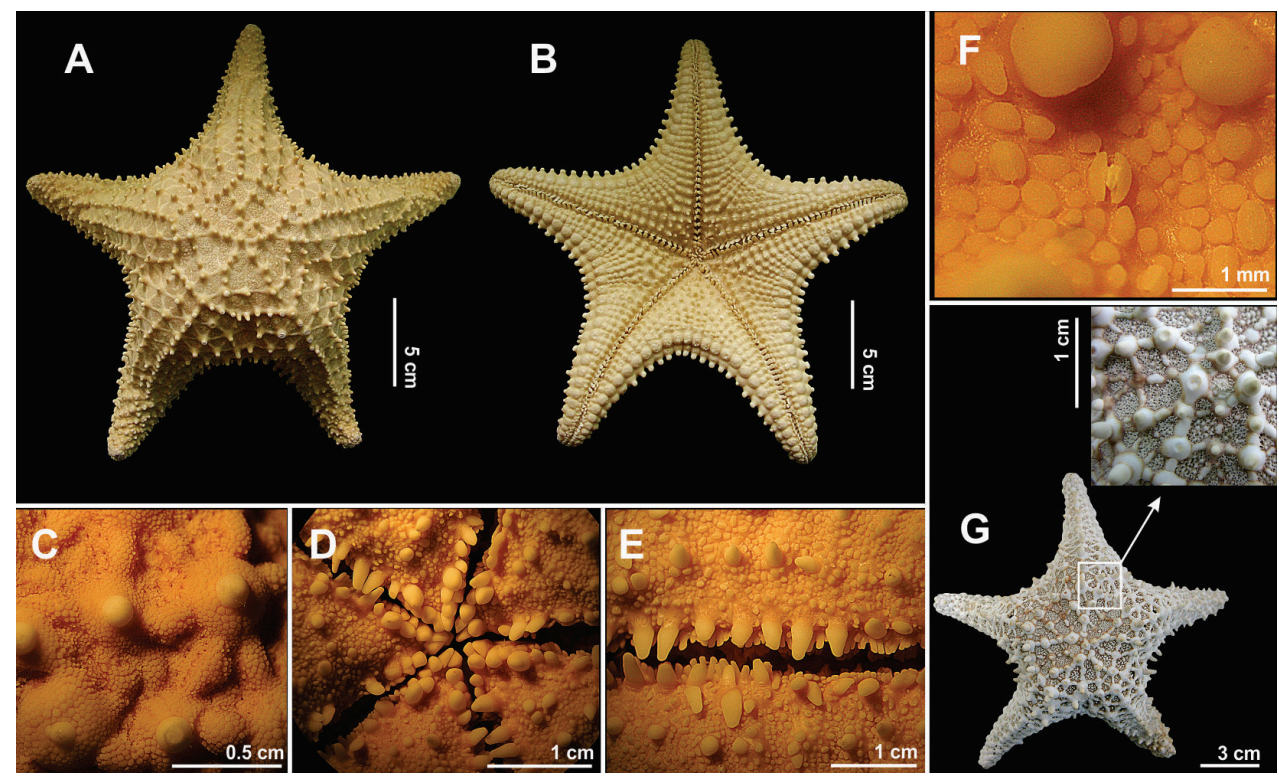

Figure 8. Some species of the order Valvatida recorded in northeastern Brazil. Oreaster reticulatus $(\mathbf{A}-\mathbf{G})$ A Abactinal view $\mathbf{B}$ Actinal view $\mathbf{C}$ Detail view da abactinal surface $\mathbf{D}$ Detail of the mouth $\mathbf{E}$ Actinal view of the arm $\mathbf{F}$ Detail of the bivalve pedicellariae, and $\mathbf{G}$ Skeleton, in detail its arrangement into a reticulum.

surface. Actinal surface granulose, with a great number of pedicellariae, especially in areas near the mouth and abulacral groove. Actinal plates with 1-2 short, conical, and blunt spines $(\sim 1.53 \mathrm{~mm})$. Ambulacral plates with 5-6 short and flattened spines, of which the median spines are the largest (Fig. 8e). Short, conical, spines $(-3.16 \mathrm{~mm})$ form a well defined row of spines on the margins of the ambulacral grooves. Four short, thick, blunt oral spines (Fig. 8d). Sessile bivalve pedicellariae distributed over entire body of animal (Fig. 8f). Skeleton formed by conical, abactinal plates interconnected by secondarily elongated and widened plates, arranged into a reticulum (Fig. 8g).

Colour. According to Hendler et al. (1995) and Verrill (1915) the colour pattern of this species is very variable, even among individuals from a same population. Along the Brazilian coast the most common colour is orange or brownish red. Yet juvenile individuals differ significantly from adults. According to Benavides-Serrato et al. (2011) and Hendler et al. (1995) the aboral surface of juveniles is frequently olive-green and usually presents green-grey or coffe-coloured spots. In the adults, on the other hand, this colour is orange with lighter or darker tubercles on the disk and arms. The oral surface in both stages is beige or cream-coloured.

Distribution. North and South Carolina, the Bermudas, the Bahamas, Belize, Guatemala, Honduras, Cuba, Nicaragua, Costa Rica, Venezuela, Brazil, and Cabo Verde (Tommasi 1970, Walenkamp 1976, Hendler et al. 1995, Ventura et al. 2007, Alvarado et al. 2008, del Valle García et al. 2008). In Brazil: MA, CE, PB, PE, AL, BA, RJ, SP, and SC, incluinding Abrolhos and Trindade Island (Rathbun 1879, Verrill 1915, Clark 1942, Tommasi 1958, 1970, Brito 1962, 1968, Lima-Verde 1969, Fernandes et al. 
2002, Magalháes et al. 2005, Xavier 2010, Miranda et al. 2012). In this study we record the species for the first time in the States of Rio Grande do Norte, and Alagoas. From 0 to $800 \mathrm{~m}$ in depth, being most abundant up to $50 \mathrm{~m}$.

Remarks. Only two species of the genus Oreaster are known for the Atlantic Ocean, Oreaster clavatus and $O$. reticulatus. The first is known only from the Island of Cape Verde, São Thomé and the Gulf of Guinea. The second, occurs widely throughout the West Atlantic, from North Carolina to the south of Brazil (Clark and Downey 1992), its known southern limit being located in the State of Santa Catarina. Oreaster reticulatus differs from its congeneric $O$. clavatus for presenting an inflated body and abactinal plates with tubercules or spines. Clark (1942) described the variety $O$. reticulatus var. bermudensis on the basis of the irregular placement of spines and papulae on the abactinal surface and of the presence of only one spine on the actinal plates. However, these characters also occur in other specimens from the Atlantic and thus do not sustain the name. According to Hendler et al. (1995) the species may attain a disk diameter of up to $500 \mathrm{~mm}$. We observed morphological variations in both juveniles and adults, but were not able to correlate these with colour patterns in this preserved material.

Ecological notes. The species lives in shallow reef environments with calm water, coastal lagoons, seagrass beds (Thalassia, Halodule and Syringodium), and mangrove channels (Benavides-Serrato et al. 2011). In this study the species was recorded in rhodolite beds and coastal reefs below $6 \mathrm{~m}$. According to Verrill (1915) Oreaster reticulatus was the most abundant species in the States of Bahia and Pernambuco. Presently it is difficult to find along the northeastern coast of Brazil, and is listed as vulnerable to extinction (Machado et al. 2008). This is an omnivorous species, feeding mainly on microorganisms from organic matter associated with the sand of seagrass beds and algal substrates. However, it is also an opportunistic predator of echinoderms, such as Tripneustes ventricosus (Lamarck, 1816) and Meoma ventricosa ventricosa (Lamark, 1816), as well as of individuals belonging to its own species and to a large variety of sponges (Hendler et al. 1995). The only known predator of adults belonging to this species is the gastropod Charonia variegata (Lamarck, 1816), while young individuals are known to be eaten by a great variety of fishes (Scheibling 1980).

\section{Order Velatida Perrier, 1884}

Family Pterasteridae Perrier, 1875

\section{Calyptraster coa Sladen, 1882}

Figure $9 \mathrm{a}-\mathrm{h}$

Calyptraster coa Sladen, 1882: 207. Tommasi 1970: 13.

Calyptraster personatus Madsen, 1947: 3-7, figs 1-2.

Material examined. MZUSP (without registration number), 1spec., W Besnardi, dredging 5142. MZUSP (without registration number), 2spec., W Besnardi, dredging 5363. 

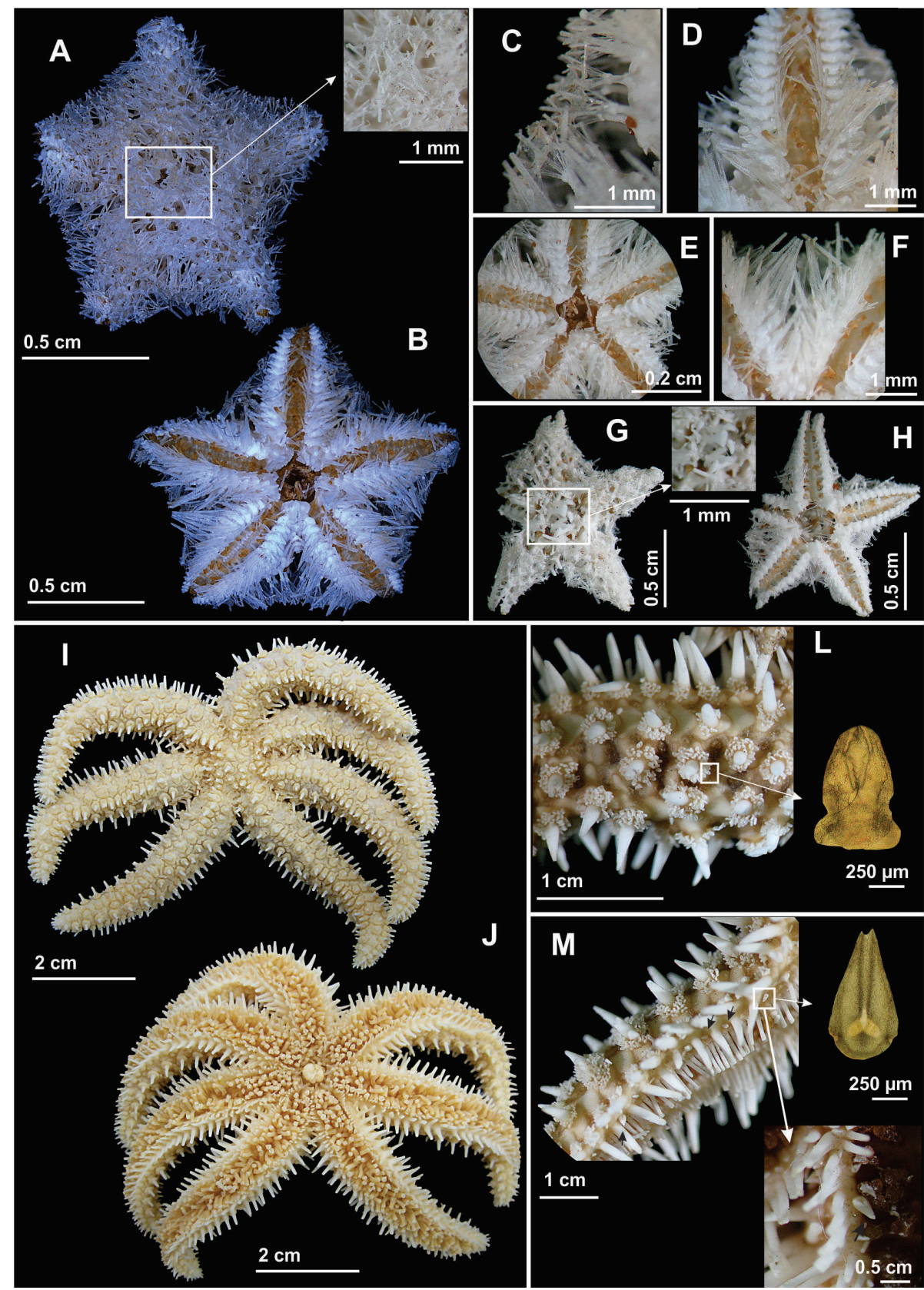

Figure 9. Some species of the order Velatida $(\mathbf{A}-\mathbf{H})$ and Forcipulatida $(\mathbf{I}-\mathbf{M})$ recorded in northeastern Brazil. Calyptraster coa $(\mathbf{A}-\mathbf{H}) \mathbf{A}$ Abactinal view, in detail the supradorsal membrane B Actinal view C Detail of the paxillae with long peduncles $\mathbf{D}$ Actinal view of the arm $\mathbf{E}$ Detail of the mouth $\mathbf{F}$ Detail of the actinal intermediate area $\mathbf{G}$ Abactinal view, in detail oscular valves $\mathbf{H}$ Actinal view; Coscinasterias tenuispina (I-M) I Abactinal view J Actinal view $\mathbf{L}$ Abactinal view of the arm, in detail the bivalve pedicallariae (optical microscopic image), and $\mathbf{M}$ Lateral view of the arms, in detail the bivalve pedicellariae (optical microscopic image). 
Type locality. Recife, Pernambuco, Brazil (Clark and Downey 1992).

Description. Body pentagonal (Fig. 9a, b, g, h). Five short arms. Supradorsal membrane thin and transparent (Fig. 9a). Spiracules moderately large, numerous, irregularly distributed. Oscule large, surrounded by long oscular valves with an enlarged extremity (Fig. 9g). Abactinal surface with paxillae. Paxillae with long peduncles and a crown of 5 to 6 long and vitreous spinelets (Fig. 9c). Skeletal plates narrow, long and vitreous, forming a reticulum. Actinal surface slightly concave. Oral spines long and vitreous, the lateral ones being longer and thicker (Fig. 9e). Adambulacral plates with three or four spines (Fig. 9d).

Colour. From light brown to hey-coloured (Sladen 1889).

Distribution. The Bahamas, Florida, and Brazil (Clark and Downey 1992). In Brazil: PE (Tommasi 1970; Clark and Downey 1992). From 260 to 933 m in depth (Clark and Downey 1992).

Remarks. The genus Calyptraster presently contains five species (Mah 2013), four of which occur in the Western Atlantic: C. coa, C. personatus (Perrier, 1885), C. tenuissimus Bernasconi, 1966 and C. vitreus Bernasconi, 1972. The first two have a similar geographical distribution, occurring from the Bahamas to Brazil and Colombia, respectively, while the last two are restricted to the coast of Argentina. According to Clark and Downey (1992), this genus is problematic, and the distinctions between C. coa and C. personatus remain to be better established. Walenkamp (1979) provides good descriptions and discusses the main morphological diferences between these species. In the phylogenetic analysis of the family Pterasteridae by Villier et al. (2004), it is concluded that Calyptraster representes a monophyletic genus. Calyptraster coa differs from $C$. personatus for having conical suboral spines, an osculum surrounded by valves with enlarged extremities, and for being distributed no deeper than $1000 \mathrm{~m}$. Specimens observed in this study were all juveniles. Smaller specimens tend to have longer arms and a more flattened body. Our material was badly preserved in general, not permitting a detailed description of their morphological characters.

Ecological notes. This species is quite rare, from deep waters, with little known of its biology and ecology. The species was collected in bottoms containing red mud (Sladen 1889).

\section{Family Ophidiasteridae Verril, 1870}

\section{Linckia guildingi Gray, 1840}

Figure $10 \mathrm{a}-\mathrm{e}, 12 \mathrm{~d}$

Linckia guildingii Gray, 1840: 285. Tommasi 1958: 17. Brito 1962: 3; 1968: 4-5, pl. 1, fig. 3; 1971: 262. Lima-Verde 1969: 11. Tommasi and Aron 1988: 3. Tommasi et al. 1988: 6. Fernandes et al. 2002: 422. Gondim et al. 2008: 154 .

Linckia pacifica Gray, 1840: 285. 
Ophidiaster ornithopus Müller \& Troschel, 1842: 31

Ophidiaster ehrenbergi Müller \& Troschel, 1842: 31

Linckia ornithopus Verrill, 1867: 344.

Linckia nicobarica Lütken, 1872: 265.

Linckia ehrenbergi Loriol, 1885: 31.

Linckia guildingi Verrill, 1907: 325. Miranda et al. 2012: 144.

Material examined. Paraíba: $6^{\circ} 29^{\prime} S$; $34^{\circ} 48^{\prime} \mathrm{W}, 1$ spec., UFPB/ECH.1235, 04.VI.1981,

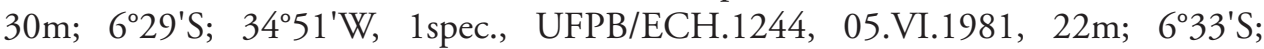
$34^{\circ} 51^{\prime} \mathrm{W}, 1$ spec., UFPB/ECH.1243, 04.VI.1981, 20m; $7^{\circ} 01^{\prime} \mathrm{S} ; 34^{\circ} 30^{\prime} \mathrm{W}, 1$ spec., UFPB/ECH.1856, 13.II.1981, 26m; 701'S; 34³0'W, 3spec., UFPB/ECH.1238, 13.II.1981, 26m; 704'S; 344'W, 1spec., UFPB/ECH.1237, 16.II.1981, 16m; $7^{\circ} 12^{\prime} 5^{\prime \prime S}$; $34^{\circ} 36^{\prime} \mathrm{W}, 1$ spec., UFPB/ECH.1241, 01.IV.1981, 26m; 7²8'S; 34³4'W, 1spec., UFPB/ECH.1242, 06.V.1981, 30m; João Pessoa, Cabo Branco Beach, 1spec., UFPB/ECH.1159, 19.II.2003. 1spec., UFPB/ECH.1160, 04.XI.2006, 1spec., UFPB/ECH.1161, 06.X.1979; 3spec., UFPB/ECH.1236, 25.X.2007, 1spec., UFPB/ ECH.1245, 16.V.2007, 1spec., UFPB/ECH.1246, 19.IV.2005; 1spec., UFPB/ ECH.1247, 08.IX.2006, 2spec., UFPB/ECH.1248, 25.X.2007, 1spec., UFPB/ ECH.1250, 03.VII.2004, 1spec., UFPB/ECH.1479, 13.XI.2008, 1spec., UFPB/ ECH.1502, 08.II.2009, 1spec., UFPB/ECH.1867, III.2007. Pernambuco: Paulista, Pau Amarelo reef, 1spec., UFPB/ECH.1845, 08.XI.1982. Alagoas: Paripueira, Paripueira Beach, 2spec., UFPB/ECH.1851, 01.II.1983; Maceió, Ponta Verde Beach, 1spec., UFSITAB-199, I.2007, 1spec., UFSITAB-200, I.2007; Marechal Deodoro, Francês Beach, 5spec., UFPB/ECH.1855, 29.I.1983, 2spec., UFPB/ECH.1847, 20.XII.1984, 1spec., UFPB/ECH.1849, 19.II.1985, 2spec., UFPB/ECH.1857, 19.II.2011. Bahia: Salvador, Itapoã Beach, 1spec., UFPB/ECH.1848, 21.XII.1984; Itaparica, Pedrão, 4spec., UFPB/ECH.1853, 18.IX.1982; Itaparica, Barra Grande, 1spec., UFPB/ECH.1854, 17.IX.1982; Santa Cruz da Cabrália, Ponta da Coroa Vermelha, 5spec., UFPB/ECH.1846, 15.X.1982; Santa Cruz da Cabrália, Ponta do Mutá reef, 5spec., UFPB/ECH.1850, 16.X.1982; Porto Seguro, Ponta Grande reef, 5spec., UFPB/ECH.1852, 15.X.1982.

Type-locality. Saint Vincent, West Indies (Clark and Downey 1992).

Description. Disk small. From four to six long, thin, cylindrical arms (Fig. 10a, b). Abactinal and actinal surfaces granuliform. Two or more madreporites. Abactinal plates rounded, inflated, irregularly arranged. Among these plates there are papular areas with 5-23 pores (Fig. 10c). Papular areas restricted to abactinal surface. Superomarginal and inferomarginal plates similar and uniform in size, separated by a row of papular areas. Actinal plates forming 2-3 series, which extend to the tip of the arms and are covered by granules a little larger than those on abactinal surface. Adambulacral plates with two short, blunt, parallel spines, one being much larger than the other (Fig. 10d). Behind these there is one wide, thick, blunt, ambulacral spine. Oral spines slightly longer $(-0.68 \mathrm{~mm})$ than remaining spines, having their tips rounded (Fig. 10e). Ocular plates also granulose. 


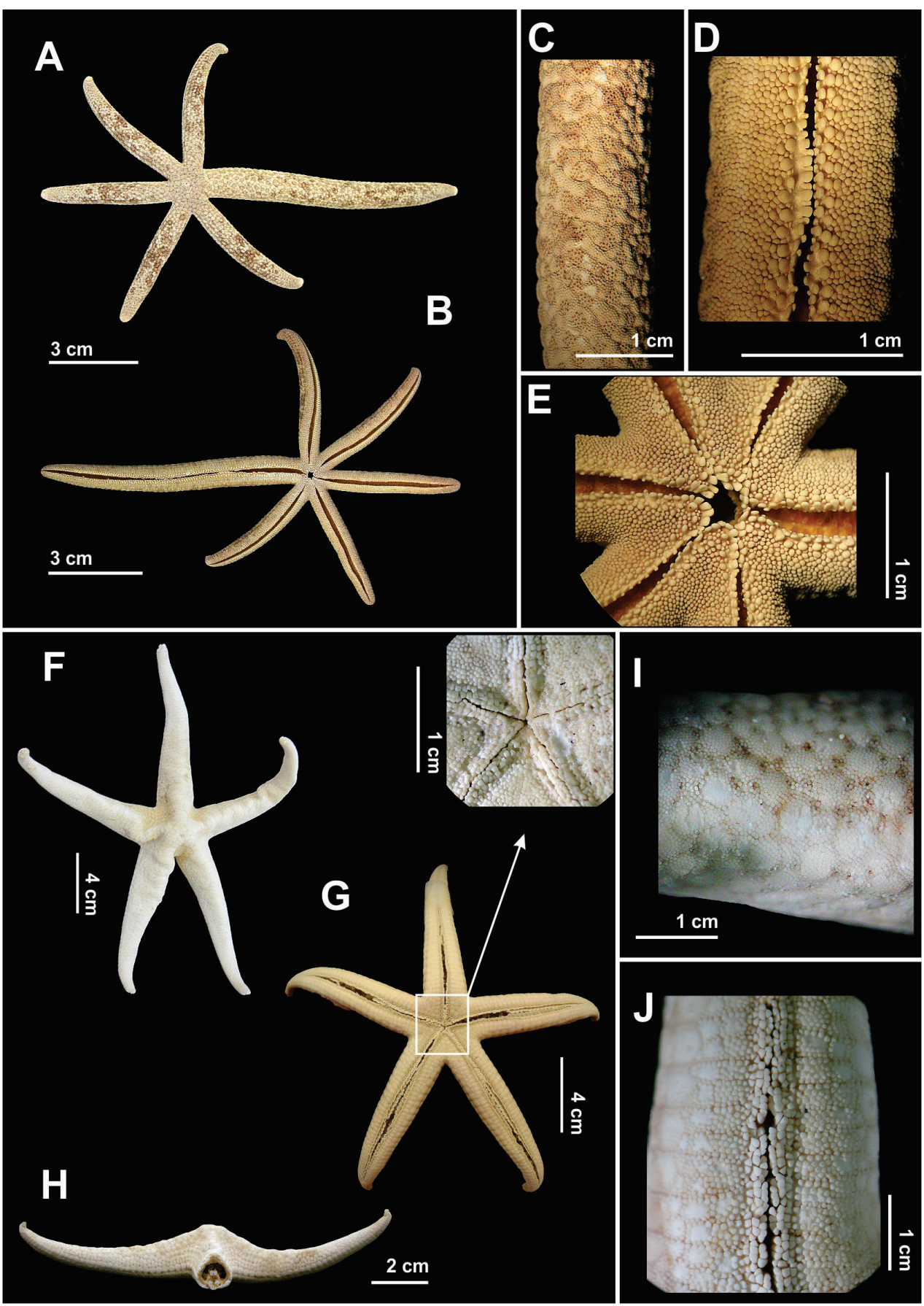

Figure 10. Some species of the order Velatida recorded in northeastern Brazil. Linckia guildingi (A-E) A Abactinal view B Actinal view $\mathbf{C}$ Abactinal view of the arm $\mathbf{D}$ Actinal view of the arm $\mathbf{E}$ Detail of the mouth; Narcissia trigonaria (F-J) $\mathbf{F}$ Abactinal view $\mathbf{G}$ Actinal view, in detail the mouth $\mathbf{H}$ Lateral view I Abactinal view of the arm, and J Actinal view of the arm. 
Colour. Extremely variable, usually juveniles and adults having different colours (Hendler et al. 1995). Juvenile individuals have brown, red or violet spots, while adults are uniformly reddish-brown, yellowish-brown, violet, or olive-green (Brito 1960, Hendler et al. 1995, Benavides-Serrato et al. 2011). In the Brazilian material the most common colour observed is brown and yellow.

Distribution. Tropicopolitan (Tommasi 1970, Alvarado et al. 2008). It also occurs throghout the tropical Indo-West Pacific. In Brazil: PB, PE, AL, BA, RJ, and SP, including Abrolhos and Trindade Island (Rathbun 1879, Verrill 1915, Bernasconi 1955, Tommasi 1958, Brito 1960, 1962, 1968, 1971, Lima-Verde 1969, Tommasi and Aron 1988, Fernandes et al. 2002, Magalhães et al. 2005, Gondim et al. 2008, Miranda et al. 2012). From 0 to $298 \mathrm{~m}$ in depth (Clark and Downey 1992).

Remarks. Two species of the genus Linckia are known for the Brazilian coast, $L$. guildingi and L. nodosa Perrier, 1875, the latter recorded only for south and southeastern Brazil. Tommasi and Aron (1988) cite Ophidiaster guildingi Gray, 1840 for southeast Bahia, a locality we were not able to confirm. Linckia guildingi differs from L. nodosa for having small triangular abactinal plates, 18-30 pores per papular area, and two subambulacral spines. Juvenile individuals of L. guildingi may be confused with Ophidiaster guildingi Gray, 1840, which have the same colour and occupy the same habitat (Hendler et al. 1995). Ophidiaster guildingi differs from L. guildingi for having less than 15 pores per papular area. Although we observed both juvenile and adult individuals, no morphological variations were noted.

Ecological notes. This species lives in environments with consolidated substrates or sand banks among reefs (Machado et al. 2008). It has cryptic habits, being found mostly under rocks. Possibly L. guildingi uses the film of microorganisms adhered to the substrate as food (Hendler et al. 1995; Machado et al. 2008). According to Brito (1971) this species is abundant along the northeastern coast of Brazil. However, its populations are becoming reduced, especially in southeastern Brazil. The species is presently included among the species vulnerable to extinction (Machado et al. 2008). L. guildingi is known for its strong propensity to autotomize and its capacity to regenerate. Specimens with four, six or seven arms are common (Tommasi 1958).

\section{Narcissia trigonaria Sladen, 1889}

Figure 10f-j

Narcissia trigonaria Sladen, 1889: 414, pl. 65, figs 5-8. Tommasi 1966: 244; 1970: 9, fig. 26. Brito 1960: 5, pl. 1, figs 4-5; 1962: 3; 1968: 5. Tommasi and Aron 1988: 3. Tommasi et al. 1988: 6. Miranda et al. 2012: 144.

Narcissia trigonaria var. helenae Mortensen, 1933: 429.

Material examined. Alagoas: Lagoa Azeda, Jequidá da Praia, 1spec., MNRJ (no registration number), 22.VI.2002. Bahia: Salvador, north coast, 1spec., UFBA00570, 
2003; Salvador, Porto da Barra, 1spec., UFBA00929, II.2008, 23m; Salvador, Barra Beach, 1spec., UFBA00962, X.2008; Itaparica, Ponta de Areia, 1252'S; 3840'W, 1spec., UFBA00469; Camaçari, Guarajuba, 1spec., UFBA00190, VII.2005, 23m; Camaçari, Guarajuba, Busca Vida Beach, 2spec., UFBA00042, 04.VI.1994, 1spec., UFBA01043, VII.2008, 26m, 1spec., UFBA01089, VII.2008, 32m.

Type-locality. Bahia, Brazil (Clark and Downey 1992).

Description. Disk high and pyramidal (Fig. 10f, h). Five long and triangular arms in transversal section (Fig. 10f, h). Abactinal and actinal surfaces granulose (Fig. 10i). Abactinal plates rounded, placed in irregular rows, covered by flattened and polygonal granules. Among these plates are papular areas with up to three papulae. Superomarginal plates short, wide $(-2.69 \mathrm{~mm})$, granulose and visible only laterally. Papular areas restricted to abactinal surface. Inferomarginal and superomarginal plates similar. Actinal plates slightly rectangular and granulose, these granules being bigger and taller than the dorsal granules. Actino-lateral plates with two rows of spines, the outer series with 4-5 short and blunt spines. The inner row is formed by 3-4 large, flattened spines, being longer than the outer row. Adambulacral plates with 3-4 series of flattened and prismatic spines, of which the innermost are the largest (Fig. 10j).

Colour. Live specimens are cream-coloured with red spots (Benavides-Serrato et al. 2011).

Distribution. North Carolina, Florida, Panama, Colombia, and Brazil (Tommasi 1970; Clark and Downey 1992; Alvarado et al. 2008; Benavides-Serrato et al. 2011). In Brazil: AL, BA, and RJ (Verrill 1915, Brito 1960, 1962, Tommasi 1970, Tommasi and Aron 1988, Miranda et al. 2012). From 5 to $91 \mathrm{~m}$ in depth (Tommasi 1970, Clark and Downey 1992).

Remarks. Narcissia trigonaria is a well established species, with a small list of synonyms and little morphological variation. It differs from $N$. canariensis (d'Orbigny, 1839) for having subambulacral spines arranged into three series and paired papulae. Downey (1973) records the sugar-tongs type of pedicellariae among the carinal plates of $N$. trigonaria. However, we did not observe this type of pedicellaria. Walenkamp (1976) gives an excellent discussion on the presence or absence of pedicellariae and on small morphological variations found in his material. He emphasizes the great morphological differences existing between juvenile and adult specimens. In general, very juvenile individuals have shorter and wider arms. These tend to become thinner and longer during ontogenetic development.

Ecological notes. The species lives in consolidated substrates, either rocks or coral (Machado et al. 2008). Presently it is considered vulnerable to extinction along the Brazilian littoral. The main causes of its populational decline are the effects of pollutants and its illegal and indiscriminate collecting for aquarium rearing (Machado et al. 2008). 


\section{Order Spinulosida Perrier, 1884 \\ Family Echinasteridae Verril, 1867}

\section{Echinaster (Othilia) brasiliensis Müller \& Troschel, 1842}

Figure 11a-e

Echinaster brasiliensis Müller \& Troschel, 1842: 22. Tommasi 1958: 22-23, pl. 4, fig. 3; 1970: 17, figs 44-45. Brito 1962: 3; 1968: 13-14, pl. 6, fig. 6. Carrera-Rodriguez and Tommasi 1977: 103-104. Tommasi and Aron 1987: 3. Tommasi et al. 1988: 6. Ávila-Pires 1983: 440-442, figs 8-9. Fernandes et al. 2002: 422. Netto 2006: 30-32, pl. 5a. Alves et al. 2010: 758. Miranda et al. 2012: 144.

Echinaster braziliensis Verrill, 1915: 41-42, pl. 26, fig. 1.

Echinaster antonioensis Bernasconi, 1955: 72-73, pl. 6, figs 1-2. Tommasi 1958: 22, pl. 4, fig. 2. Brito 1968: 15.

Echinaster sentus Bernasconi, 1956: 136-137, pl. 4, fig. 3. Tommasi 1958: 23-24, pl. 4, fig. 4; 1970: 17-18, fig. 46 a 48. Brito 1968: 14, pl. 6, figs 3-4.

Echinaster spinulosus Bernasconi, 1956: 138-139, pl. 4, fig.4. Tommasi 1958: 21-22, pl. 4, fig. 1. Brito 1968: 14, pl. 6, fig. 1-2.

Echinaster densispinulosus Tommasi, 1970: 18-19, figs 49-51.

Echinaster nudus Tommasi, 1970: 18-19, figs 52-54. Gondim et al. 2008: 154.

Echinaster (Othilia) brasiliensis Clark \& Downey, 1992: 21-22, pl. 4a. Hopkins et al.

2003: 98-100. Machado et al. 2008: 182-183. Lima and Fernandes 2009: 59.

Xavier 2010: 75.

Material examined. Rio Grande do Norte: Macau, Diogo Lopes, 1spec., UFPB/ ECH.869, 09.XI.2007, 1spec., UFPB/ECH.872, 09.XI.2008, 1spec., UFPB/ ECH.1426, 09.XI.2007. Paraíba: $7^{\circ} 01^{\prime} 02^{\prime \prime S}$; 3447'55"W, 1 spec., UFPB/ECH.571, 03.VI.2003; 703'50"S; 344ㄱ'19"W, 1spec., UFPB/ECH.569, 21.III.2006; Cabedelo, Farol de Cabedelo reef, 1spec., UFPB/ECH.729, 26.X.1980; Cabedelo, Areia Vermelha reef, 1spec., UFPB/ECH.1465, 22.II.2008; João Pessoa, Cabo Branco Beach, 2spec., UFPB/ECH.138, 04.XI.2006; João Pessoa, Seixas reef, 1spec., UFPB/ ECH.1183, 22.XII.2007. Bahia: Santo Amaro, Cabuçu Beach, 3spec., UFPB/ ECH.718, 19.IX.1987.

Type-locality. Ubatuta, São Paulo, Brazil (Walenkamp 1976).

Description. Disk small (Fig. 11a). Body concave on abactinal surface, plane on actinal surface. Five long-narrow to short-thick arms (usually decreasing rapidly in thickness towards tips) (Fig. 11a, b). Abactinal plates flattened or slightly mammiform (Fig. 11e), forming a reticulum and bearing a short, conical spine (Fig. 11c). Abactinal plates separated by small, elongated, secondary plates. Anus normally placed within the central pentagon of the disk and surrounded by 4-6 spines. Madreporite circular, with numerous small granules and irregular sulci. Superomarginal plates more granulose than inferomarginal plates. Papular areas more numerous on dorsal and lateral regions of arms (Fig. 11c). Adambulacral plates with three spines, 

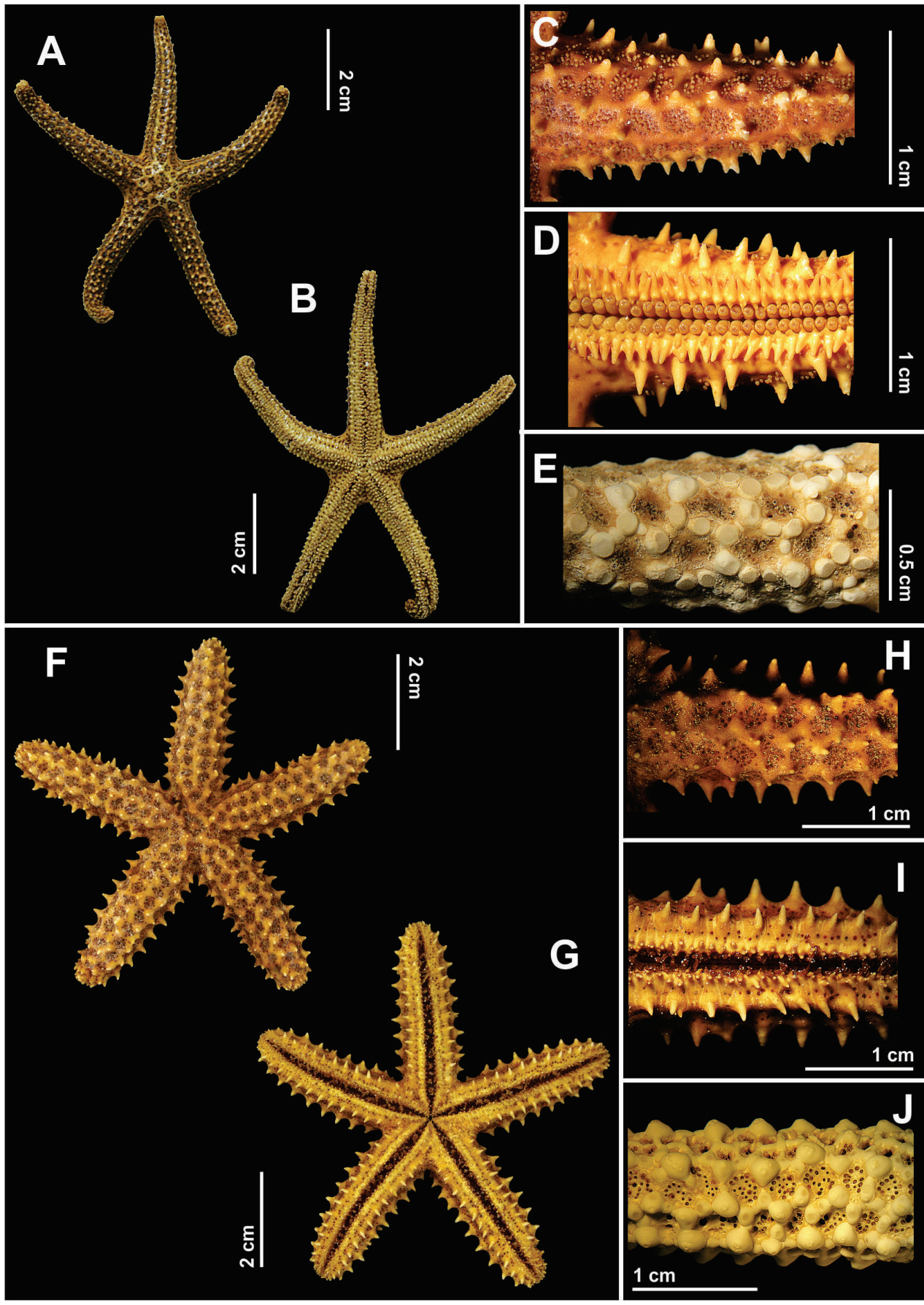

Figure II. Some species of the order Spinulosida recorded in northeastern Brazil. Echinaster (Othilia) brasiliensis (A-E) A Abactinal view B Actinal view $\mathbf{C}$ Abactinal view of the arm $\mathbf{D}$ Actinal view of the arm E Arranjo do endoqesquelto do braço; Echinaster (Othilia) echinophorus (F-J) F Abactinal view $\mathbf{G}$ Actinal view $\mathbf{H}$ Abactinal view of the arm $\mathbf{I}$ Actinal view of the arm; and $\mathbf{H}$ Arranjo do endoesqueleto do braço. 
the inner one being rudimentary (Fig. 11d). The two outer spines are subequal and larger than the remaining spine.

Colour. Quite variable, being light brown, reddish-brown, dark red or even yellowish red (Gray et al. 1968; Benavides-Serrato et al. 2011).

Distribution. Florida, Cuba, Honduras, Panama, Colombia, Brazil, and Argentina (Tommasi 1958, Alvarado et al. 2008, Benavides-Serrato et al. 2011). In Brazil: PB, PE, AL, BA, ES, SP, RJ, SC, and RS (Verrill 1915, Tommasi 1958, Carrera-Rodriguez and Tommasi 1977, Fernandes et al. 2002, Magalhães et al. 2005, Gondim et al. 2008, Xavier 2010, Miranda et al. 2012). This paper provides the first record for the State of Rio Grande do Norte. From 1 to $360 \mathrm{~m}$ in depth (Benavides-Serrato et al. 2011).

Remarks. Many characters of Echinaster (O.) brasiliensis and other species of the genus present great plasticity, with the consequence that the taxonomy of the genus cannot be considered well resolved. E. (O.) brasiliensis differs from $E$. (O.) echinophorus for presenting a larger number of rows of dorsal longitudinal spines (9-15) and actinal plates not mammiform. E. (O.) sentus differs for having more numerous and shorter dorsal spines and for having mammiform abactinal plates. Walenkamp (1976) pointed out some variations observed in specimens from Suriname, such as: number of adambulacral spines (from 2 to 5), number of spines per dorsal longitudinal row (from 1 to 15), and size of the dorsal papular areas. In our study, as well as the large plasticity in the number of dorsal longitudinal spines (from 7 to 13), a character used as diagnotic for the genus, the number of spines surrounding the anus and the shape of the arms also proved to be quite variable. However, these morphological variations do not seem to be related to ontogenetic stages. Despite both adults and juveniles being present in our material, these variations occurred among specimens of a same size class. According to Machado et al. (2008), the most common shape of $E$. (O.) brasiliensis presents narrow and elongate arms, while a smaller proportion of individuals have short and thick arms and less numerous spines. Tommasi (1970) synonymized E. (O.) antonioensis De Loriol, 1904 with E. (O.) brasiliensis, though without providing further details. According to him (Tommasi op. cit.) the characters used by De Loriol to distinguish the two species are all dependent on fixation mode or represent highly variable characters. An excelent discussion on the synonyms of the several species of $E$. (O.) brasiliensis is found in Clark and Downey (1992). Avila-Pires (1983) proposed the presence of only two species of Echinaster for the Brazilian littoral, E. (O.) echinophorus being restricted to the northeastern coast and $E$. (O.) brasiliensis to the south and southeastern coast. We disagree with this opinion, suggesting that $E$. (O.) brasiliensis also occurs in northeastern Brazil. More taxonomic studies are clearly needed in order to better establish the interspecific limits between these two species.

Ecological notes. This species lives in sand, substrates of sand with mud, and consolidated substrates, often associated with the bivalves Mytillus sp. and Lithophaga sp. (Penchaszadeh 1973), having also been observed in banks of Thalassia sp. (Benavides-Serrato et al. 2011). Echinaster (O.) brasiliensis is frequently found in intertidal regions or shallow waters, and may be strongly influenced by water salinity (Machado et al. 2008). In this study, the species was found mainly in reef environments and 
hypersaline mangrove areas, always together with $E$. (O.) echinophorus. According to Machado et al. (2008), this species is common along the coast of Rio de Janeiro, being intensively collected by aquarists without futher control on their extraction and commercialization. Alves and Dias (2010) recorded its use for medical purposes (treatment of asthma). E. (O.) brasiliensis is listed among the species vulnerable to extinction (Machado et al. 2008).

\section{Echinaster (Othilia) echinophorus (Lamarck, 1816)}

Figures $11 \mathrm{e}-\mathrm{j}, 12 \mathrm{e}-\mathrm{f}$

Asterias spinosa Retzius, 1805: 18.

Asterias echinophora Lamarck, 1816: 560.

Stellonia spinosa Nardo, 1834: 716.

Othilia spinosa Gray, 1840: 281.

Echinaster spinosus Müller \& Troschel, 1842: 22.

Echinaster (Othilia) crassispina Verrill, 1868: 368.

Echinaster crassispinus Lütken, 1872: 285.

Echinaster echinophorus Perrier, 1875: 100-102. Brito 1962: 3. Lima-Verde 1969: 11. Avila-Pires 1983: 436-440, figs 6-7. Tommasi 1970: 16-17, figs 41-43. Tommasi and Aron 1988: 3. Fernandes et al. 2002: 422. Gondim et al. 2008: 155, fig. 3a. Alves et al. 2010: 757. Miranda et al. 2012: 144.

Othilia echinophora Fisher, 1919: 432.

Echinaster (Othilia) echinophorus Clark \& Downey, 1992: 367-371. Magalhães et al. 2005: 63. Machado et al. 2008: 183-184. Lima and Fernandes 2009: 59. Gondim et al. 2011: 6, fig. 3e.

Material examined. Rio Grande do Norte: Macau, Diogo Lopes, 4spec., UFPB/ ECH.871, 09.XI.2007; Tubarão River, 1spec., UFPB/ECH.1905,14.XI.2009; Tubarão River Mangrove, 1spec., UFPB/ECH.1904, 31.I.2011; 1spec., UFPB/ ECH.1913, 04.IX.2010; Mangrove on highway to Galinhos, 1spec., UFPB/ ECH.1914, 22.VI.1982. Paraíba: 703'50"S; 3447'19"W, 2spec., UFPB/ECH.568, 21.III.2006; Lucena, Fagundes Beach, 2spec., UFPB/ECH.717, 22.IX.1995, 1spec., UFPB/ECH.728, 22.IX.1985; Cabedelo, Areia Vermelha reef, 2spec., UFPB/ ECH.1464, 06.IV.2008; Cabedelo, Poço Beach, reefs facing Ponta de Campina, 1spec., UFPB/ECH.1903, 28.II.2010; João Pessoa, 7²'30” S; 3446'56”, 1 spec., UFPB/ECH.725, 26.IV.2005; João Pessoa, Cabo Branco Beach, 3spec., UFPB/ ECH.704, 2002, 4spec., UFPB/ECH.705, 9spec., UFPB/ECH.706, 04.IV.1981, 4spec., UFPB/ECH.707, 03.VII.1985, 1spec., UFPB/ECH.708, 17.II.1980, 1spec., UFPB/ECH.710, 01.IV.2006, 1spec., UFPB/ECH.711, V.1980, 2spec., UFPB/ ECH.713，06.XI.1983，10spec., UFPB/ECH.714, 29.IV.2002，3spec., UFPB/ ECH.715, 13.XII.1985, 1spec., UFPB/ECH.719, 22.IX.1980, 3spec., UFPB/ ECH.722, 09.II.2001, 1spec., UFPB/ECH.727, 09.IX.2006, 3spec., UFPB/ECH.870, 

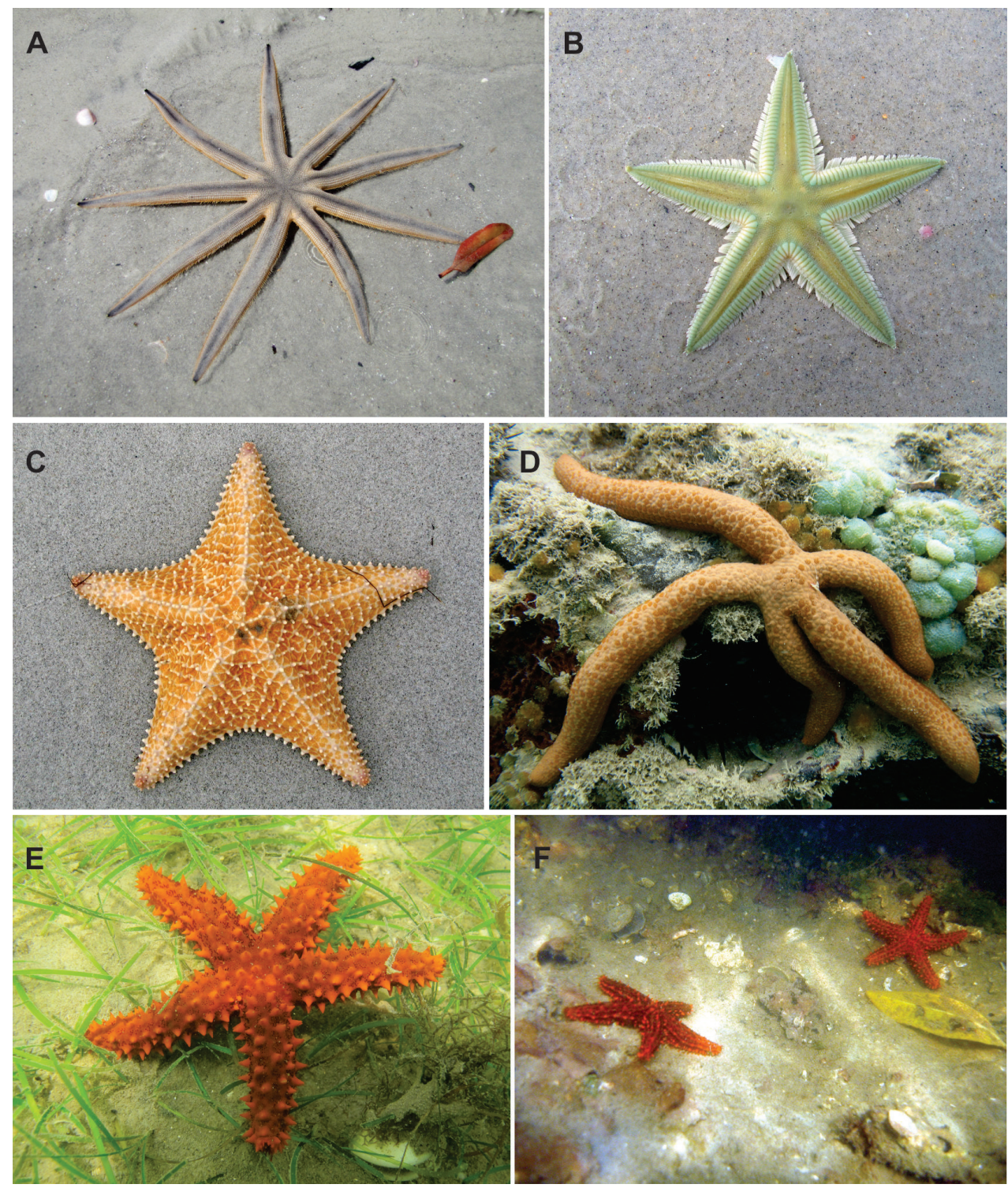

Figure 12. Some common starfishes in their natural habitat. A Luidia senegalensis in a sand beach B Astropecten marginatus in a hypersaline mangrove $\mathbf{C}$ Oreaster reticulatus in a sand beach $\mathbf{D}$ Linckia guildingi on coral reefs $\mathbf{E}$ Echinaster $(O$.) echinophorus in seagrass beds and $\mathbf{F} E$. (O.) echinophorus over the muddy bottom of a hypersaline mangrove. Photos: Thelma LP Dias.

25.XI.2007, 1spec., UFPB/ECH.1240, 22.IX.1980, 2spec., UFPB/ECH.1466, 13.XI.2008, 1spec., UFPB/ECH.1911, 21.III.2000; João Pessoa, Ponta Seixas, 6spec., UFPB/ECH.139, 03.XI.1982, 3spec., UFPB/ECH.703, 23.X.1984, 2spec., UFPB/ ECH.712, 25.V.1998; Seixas reef, 1spec., UFPB/ECH.1172, 23.III.2008, 6spec., UFPB/ECH.1234, 03.XI.1982. 4spec., UFPB/ECH.1184, 22.XII.2007, 2spec., 
UFPB/ECH.1463, 12.I.2009. Pernambuco: Goiana, Catuama Beach, 1spec., UFPB/ ECH.1912, 31.X.1982. UFPB/ECH.873; Tamandaré, Carneiros Beach, 4spec., 15.X.1981. Alagoas: Marechal Deodoro, Francês Beach, 1spec., UFPB/ECH.721, 29.I.1983. Bahia: Itaparica, Pedrão de Itaparica, 8spec., UFPB/ECH.716, 18.IX.1982; Itaparica, Ponta de Aratuba, 7spec., UFPB/ECH.723, 19.X.1982; Itaparica, Barra Grande, 2spec., UFPB/ECH.726, 19.IX.1982; Prado, coral reef between Camaruxatiba and Ponta de Imbaçuaba, 3spec., UFPB/ECH.709, 14.X.1982, 2 spec., UFPB/ ECH.724, 28.XI.1982; Santa Cruz da Cabrália, Ponta da Coroa Vermelha, 5spec., UFPB/ECH.720, 15.X.1982.

Type-locality. 'Amérique du Nord' (lectotype) (Clark and Downey 1992).

Description. Disk small (Fig. 11f). Body convex dorsally and flattened ventrally. Five (rarely three to six) short and thick arms, with a robust skeleton (Fig. 11f, g). Abactinal plates mammiform (Fig. 11j), with one large spine. Seven to 11 series of dorsal longitudinal spines. Anus normally positioned within central pentagone of disk and surrounded by 4-6 spines. Madreporite circular with numerous small granules and irregular grooves. Papular areas more numerous on abactinal and lateral regions of arms (Fig. 11h). Papular areas on actinal surface small and widely dispersed. Adambulacral plates with 3 to 4 spines arranged transversally (Fig. 11i).

Colour. Red, orange-red, becoming brownish-red when conserved in alcohol and dark brown when dry (Verril 1915, Hendler et al. 1995).

Distribution. Florida, the Bahamas, Gulf of Mexico, Puerto Rico, Jamaica, Nicaragua, Colombia, Venezuela, and Brazil (Alvarado 2011, Benavides-Serrato et al. 2011). In Brazil: CE, RN, PB, PE, AL, BA, ES, and RJ, including Abrolhos (Verrill 1915, Krau 1950, Brito 1962, Lima-Verde 1969, Tommasi 1970, Avila-Pirez 1983, Fernandes et al. 2002, Magalháes et al. 2005, Miranda et al. 2012). From 0 to $55 \mathrm{~m}$ in depth (Hendler et al. 1995).

Remarks. Echinaster (O.) echinophorus differs from E. (O.) sentus for having few large and conspicuous spines on arms and a uniform colour (Hendler et al. 1995). It differs from $E$. (O.) brasiliensis for having thicker arms and mammiform abactinal plates. According to Atwood (1973), E. (O.) echinophorus appears to contain several morphologically distinct forms or closely related species. For Walenkamp (1979) the number of series of dorsal longitudinal spines, which Perrier considered to be the main character for separating species in the genus, is quite variable. The examined specimens have a broad morphological variation, among which: number of rows of dorsal longitudinal spines (from 7 to 9), number of spines surrounding the anus (from 4 to 6 ) and number of granules on the madreporite (from 8 to 15). Notwithstanding, these morphological variations do not seem to be related to ontogenetic development, because even though specimens examined included both juvenile and adult individuals, the differences also affected specimens of the same size. An excellent discussion of the synonymies proposed for the different species of $E$. (O.) echinophorus and of the taxonomic history of the species is found in Clark and Downey (1992) and Walenkamp (1979).

Ecological notes. Lives usually in environments containing consolidated substrates (Hendler et al. 1995), and may be found in estuarine regions (Nobre and 
Campos-Creasey 2000). It feeds preferably on incrustating organisms belonging to the epifauna and on organic detritus deposited in the substrate (Jangoux and Lawrence 1982). Kempf (1966) found that E. (O.) echinophorus may occur in salinities up to 47. We found it in salinities of 52 (Tubarão River/Rio Grande do Norte), forming dense populations. Alves and Dias (2010) commented on the use of this species for medicinal purposes and Machado et al. (2008) remarked that one of the main threats relates to its collecting for aquarists. Presently it is included among the Brazilian species vulnerable to extinction (Machado et al. 2008).

\section{Order Forcipulatida Perrier, 1884 Family Asteriidae Gray, 1840}

\section{Coscinasterias tenuispina (Lamarck, 1816)}

Figure $9 \mathrm{i}-\mathrm{m}$

Asterias tenuispina Lamarck, 1816: 561-562.

Asteracanthion tenuispinus Müller \& Troschel, 1842: 16.

Asterias atlantica Verrill, 1868: 368. Rathbun 1879: 145.

Asterias (Stolasterias) tenuispina Sladen, 1889: 565, 583.

Polyasterias tenuispina Perrier, 1894: 108.

Lytaster inaequalis Perrier, 1894: 98-99.

Coscinasterias tenuispina Verrill, 1914: 45. Brito 1960: 4; 1962: 2. Netto 2006: 34, fig.

16c, pl. 5b. Ventura et al. 2007: 228.

Coscinasterias tenuispina var. atlantica Verrill, 1915: 20-21. Tommasi 1966: 24-244.

Stolasterias tenuispina Verrill, 1907: 324.

Coscinasterias (Stolasterias) tenuispina Fisher, 1926: 197.

Material examined. Rio de Janeiro: Cabo Frio, Formoso Beach, 1 spec., MZUSP (without registration number), VII.1956; Cabo Frio, Arraial do Cabo, Brava Beach, 1spec., MZUSP (without registration number), 29.I.2001.

Type locality. 'I' ocean eropéen' (Clark and Downey 1992).

Description. Disk small, with 1-3 madreporites (in some cases up to 5 were observed). Six to nine (rarely 5 and unusually 7 ) thin, elongate (Fig. 9i, j), cylindrical arms, usually of different sizes, the larger ones grouped to one side and the smaller ones to the opposing side. Abactinal plates with one long, conical and pointed spine $(-2.17 \mathrm{~mm})$, with base densely surrounded by bivalve pedicallariae with overlapping valves (Fig. 9l). Carinal plates arranged in a regular series. Dorso-lateral plates forming a reticulum. Papular regions occuring on the abactinal and actinal surfaces. Among the abactinal plates, mainly in the intermediate areas, large bivalve pedicellariae are found. Pedicellariae of dorsal spines sessil and with overlapping bivalves, with denteate margins. Oral pedicallariae bivalve (Fig. 9m), consisting of a basal piece into which two valves with smooth margins fit in. 
Colour. Specimens from Brazil vary from brown to orange colour (Ventura et al. 2007). According to Clark and Downey (1992), specimens from the Mediterranean are usually yellow or whitish-yellow with black or brown spots on abactinal surface and crowns of rusty-red pedicellariae. Individuals from the Bermudas, on the other hand, with dorsal surface purple and the oral surface yellow, blue or violet (Verrill 1915).

Distribution. North Carolina, Gulf of Mexico, Antilles, Bermudas, Cuba, Brazil, Portugal, Spain, France and Montenegro (Tommasi 1970, Downey 1973, Clark and Downey 1992, Alves et al. 2002, Waters and Roy 2003, Kascelan and Mandic 2007). In Brazil: BA, ES, and SP, including Abrolhos (Rathbun 1879, Verrill 1915, Brito 1960, Tommasi 1970, Ventura et al. 2007). Intertidal to $165 \mathrm{~m}$ in depth (Clark and Downey 1992).

Remarks. Two species of the genus Coscinasterias Verrill, 1870 are known for the Atlantic, C. tenuispina and C. calamaria (Gray, 1840). The first is widely distributed through the Atlantic and Mediterranean, while the second is restricted to South Africa, Angola, and Madagascar (Mah 2013). C. tenuispina differs from C. calamaria for having intercrossing pedicellariae with a well developped terminal tooth (except in some specimens from Brazil). Clark and Downey (1992) suggested a subspecific distinction for these species on the basis of morphological similarities observed in Brazilian and South African specimens. However, according to Waters and Roy (2003) these observations were made on the basis of juvenile specimens and it is thus necessary to undertake new morphological analyses to clarify the close relationships between $C$. calamaria and C. tenuispina (Waters and Roy 2003). In the phylogeographic analysis of Waters and Roy (op. cit.) for species of Coscinasterias, morphological variations were observed between populations from Brazil on the one side and from the Bermudas and the Mediterranean on the other. No morphological variations are observed in the specimens examined by us.

Ecological notes. Lives in consolidated substrates, including areas with strong hydrodynamism (Machado et al. 2008). Coscinasterias tenuispina has extra-oral digestion and feeds on epifaunal organisms, mainly mussels (Ventura et al. 2007). It is a fissiparous species, which presents an annual gonadal cycle and a long period of spawning (Alves et al. 2002). According to these authors, the preponderance of males in the population of Itaipu Beach (Niterói/Rio de Janeiro) suggests that assexual reproduction by fission is predominant and, consequently, that the number of clones must be significant. According to Brito (1962), this species is very common in Cabo Frio (Rio de Janeiro). However, since the first record by Rathbun (1879) of C. tenuispina for Abrolhos (Bahia), the species has not been cited again off the northeast region of Brazil. As pointed out by Machado et al. (2008), although this species has a wide geographical distribution, its range is discontinuous, probably due to its assexual reproduction, that limits dispersal ability. Presently the species is listed among those vulnerable to extinction, having among the main causes of population decline the constant destruction of its habitat, the erosion of the substrate, the effects of pollutants, the precarious sanitation and the excess of tourists and divers within their range of occurrence (Machado et al. 2008). 


\section{Discussion}

The fauna of Asteroidea recorded for northeastern Brazil is composed mainly by species with broad geographical and bathimetic distributions, and considered common species for the Brazilian littoral (Tommasi 1970). One exception is Mithrodia clavigera, which represents a new record for the northeast and is typically a species of deeper waters. Another two species represent new records for northeast Brazil: Astropecten alligator and Luidia ludwigi scotti.

Among the four recorded orders, Paxillosida was the nost diverse ( $\mathrm{n}=10 \mathrm{spp}$ ), followed by Valvatida ( $\mathrm{n}=5 \mathrm{spp})$, Velatida $(\mathrm{n}=3 \mathrm{spp})$, Spinulosida $(\mathrm{n}=2 \mathrm{spp})$ and Forcipulatida $(\mathrm{n}=1 \mathrm{spp})$. These results were expected, because Paxillosida represents the most diverse order and contains the most speciose genus (Astropecten with $150 \mathrm{spp}$ ) and abundant species in shallow waters (Zulliger et al. 2010). Although common in marine communities, the taxonomy of the species composing this order and the phylogenetic relationships of the Paxillosida are still uncertain and contradictory (Matsubara et al. 2005). During many years this order was considered to be the most primitive in the class, due mainly to the absence of an anus and of ventosae on the ambulacral feet (Jangoux 1982). However, a reexamination of characters evidenced that these characters represent adaptations to life in sandy environments that produced character losses instead of being primitive absences (Matsubara et al. 2005).

The genus Astropecten represents one of the most complex taxa within the class Asteroidea, in which species exibit great morphological plasticity, making identification of species difficult. According to Zulliger et al. (2010), the high phenotypic variability of this genus resulted in the naming of several subspecies. Six of these were recognized in Brazil (Tommasi 1970). Presently they are all synonymized (Clark and Downey 1992; Mah 2013) and the records of Astropecten armatus for the Brazilian coast represent synonyms of $A$. brasiliensis (Tommasi 1999, unpublished data). Among the several taxonomic characters used for the identification of species, the appearance of the paxillae and of the superomarginal plates, together with the number and shape of the spines of the marginal fringe are the characters that contribute most for the identification of species. On the other hand, the number and shape of the adambulacral spines, characters that were much used by authros such as Bernasconi $(1955,1957)$, Tommasi (1970) and Clark and Downey (1992), proved to be very similar among specimens and were thus not considered to be good characters for the taxonomy of the genus.

Another taxonomicly complex genus is Echinaster that, similarly to Astropecten, presents large morphological variability, making species identification difficult. According to Clark and Downey (1992), the species of this genus occurring in Brazil are polymorphic, with possible hybridization among them. Presently three occurrences of Echinaster (Othilia) are considered valid along the Brazilian coast: E. (O.) brasiliensis, E. (O.) echinophorus, and E. (O.) guyanensis. According to Avila-Pires (1983), the first occurs only in the south and southeastern regions, below Espírito Santo, and the second is restricted to the northeastern region. That author does not confirm the presence of Echinaster $(O$.) guyanensis, but Clark and Downey (1992) indicate its distribution as being from Cen- 
tral America to Belém (Pará). Magalhães et al. (2005) recorded E. (O.) guyanensis for the littoral of Bahia, but this occorrence could not be confirmed in the present study. On the basis of the material we examined we cannot agree with Avila-Pires (1983) that $E$. $(O$.$) brasiliensis does not occur in the northeastern region. We confirm its presence$ in northeastern Brazil, although it is rarer there than its congener $E$. (O.) echinophorus. Among the several characters used in the taxonomy of the genus, the aspect of the endoskeleton plates represent one of the most important criteria for species recognition. The number of spine rows on the arms was used by Avila-Pires (1983) and Bernasconi (1957) to separate species, but it turned out be be quite variable in this study.

In terms of diversity, the fauna of asteroids in northeastern Brazil represent only $27 \%$ of the species known for Brazil, the coast of Bahia ( $\mathrm{n}=14 \mathrm{spp})$ and Paraíba ( $\mathrm{n}=$ $12 \mathrm{spp}$ ) being the most diverse, followed by Pernambuco ( $\mathrm{n}=9 \mathrm{spp})$, Ceará and Rio Grande do Norte (both with $6 \mathrm{spp}$ ), Alagoas ( $\mathrm{n}=4 \mathrm{spp}$ ), and Piauí ( $\mathrm{n}=2 \mathrm{spp})$. There are still no records of asteroids for the coasts of Maranhão and Sergipe. These numbers indicate the scarce knowledge available on the Asteroidea from northeast Brazil, which represents one of the least known areas regarding the benthic macrofauna (Ventura et al. 2007). The species refered for northeast Brazil ( $\mathrm{n}=21 \mathrm{spp}$ ) are mostly shallow water species (up to 30 meters in depth), with only 4 species representing deep-water forms. It remains crucial to conduct inventories in little explored areas such as northeast Brazil, particularly in deep waters.

Presently 374 species of sea-stars are known for the Atlantic Ocean (Clark and Downey 1992), the Gulf of Mexico being the most speciose area, with 126 recorded species (Pawson et al. 2009), followed by the Caribbean, with 116 spp (Alvarado et al. 2011). The fauna from Brazil represents only $20.5 \%$ of the known species from the Western Atlantic, while those from northeast Brazil represent 4.82\%. Considering the similarity of the Brazilian fauna with the Caribbean region, and taking into account the extent of the Brazilian coastline, the necessity to make an inventory and to describe the Brazilian fauna becomes urgent. According to Marques and Lamas (2006), the degree of knowledge of the marine fauna from Brazil is far from ideal and the most notable gap in our knowledge refers to the the invertebrates mainly from northeast Brazil.

Another three species recorded previously for northeast Brazil were not confirmed in the present study: Allostichaster hartti (as Leptasterias hartii Rathbun, 1879) was recorded as a rare species for the littoral of the State of Bahia (Brito 1962); Asterina stellifera (Möbius, 1859) (as Enoplopatiria marginata (Hupe, 1857)) was cited by Bernasconi (1955) for the Abrolhos Archipelago and Echinaster (O.) guyanensis was recorded by Magalhães et al. (2005) for the coast of Bahia. Ventura et al. (2007) cited A. acutiradiatus, $N$. arenatus and $P$. dentatus for the continental shelf of Bahia. Unfortunately, we have been unable to retrieve these species in the present study.

Due to the negligible previous knowledge on the Asteroidea from the littoral of northeastern Brazil, the present study represents an important re-evaluation of the diversity of this group for this area. It should further be noted that the study of material deposited in scientific collections turned out to be of fundamental importance, permitting a historical panorama of the Asteroidea from northeast Brazil. Deep-water sampling in the studied 
region, restricted to sporadic expeditions, as accounted for in Clark and Downey (1992), has still not provided many published records on asteroids. The diversity of the deep-water and abyssal marine fauna of the South West Atlantic perhaps remains the least known in the world, and clearly represents the next marine frontier to be systematically sampled and studied, both for asteroids and for other marine groups.

\section{Acknowledgements}

We are grateful to Dr. Carlos R. R. Ventura (MNRJ), Aline Benetti (MZUSP), Carla M. Menengola (MZUFBA) and Cynthia L. C. Manso (UFS) for permitting us to examine material deposited under their charge. Special thanks to Rosana Cunha and Luciana Martins for sending photos of some of the studied species, and José Anderson Feijo for making the map. We also thank the logistical support provided by the colleagues Luis Carlos, Mariana Contins, and Carlo Magenta. We are also grateful to the Federal University of Paraíba and to the Post Graduate Program in Biological Sciences (Zoology), for providing the infrastructure enabling this research. Anne I. Gondim was supported by CAPES (the Brazilian Ministry of Education) through a Master's scholarship and Martin L. Christoffersen is supported by a CNPq productivity research grant (Process number: 300198/2010-8). We wish to express our sincere gratitude to two anonymous reviewers for their critical reading of the manuscript and constructive comments. We also thank all the people who somehow contributed in this study.

\section{References}

Abreu-Pérez M, Solís-Marín FA, Laguarda-Figueras A (2005) Catálogo de los equinodermos (Echinodermata: Asteroidea y Ophiuroidea) nerítico-bentónicos del Arquipiélago Cubano. Revista de Biologia Tropical 53: 29-52.

Agassiz A (1877) North American Starfishes. Memories of the Museum of Comparative Zoology at Harvard 5: 1-136.

Alvarado JJ (2011) Echinoderm diversity in the Caribbean Sea. Marine Biodiversity 41: 261285. doi: 10.1007/s12526-010-0053-0

Alvarado JJ, Solís-Marín FA, Ahearn C (2008) Equinodermos (Echinodermata) del Caribe Centroamericano. Revista de Biologia Tropical 56: 37-55.

Alves RRN, Dias TLP (2010) Usos de invertebrados na medicina popular no Brasil e suas implicaçôes para a conservação. Tropical Conservation Science 3: 159-174.

Alves LS, Pereira AD, Ventura CRR (2002) Sexual and asexual reproduction of Coscinasterias tenuispina (Echinodermata: Asteroidea) from Rio de Janeiro, Brazil. Marine Biology 140: 95-101. doi: 10.1007/s002270100663

Avila-Pires TCS (1983) Contribuição ao estudo do gênero Echinaster Müller \& Troschel, 1840

(Echinodermata: Asteroidea) no litoral brasileiro. Anais da Academia Brasileira de Ciências 55: 431-448. 
Atwood DG (1973) Larval development in Echinaster echinophorus. Biological Bulletin 144: 1-12. doi: $10.2307 / 1540143$

Bell FJ (1882) Descriptions of new or rare species of Asteroidea in the collection of the British

Museum. Proceedings of the Zoological Society of London, Journal of Zoology, 121-124.

Bell FJ (1917) Echinodermata. 1. Actinogonidiata. British Antarctic “Terra Nova” Expedition, 1910, Zoology 4: 1-10.

Benavides-Serrato M, Borrero-Pérez GH, Solano OD, Navas GR (2005) Listado taxonômico de los asteroideos (Echinodermata: Asteroidea) de la plataforma y talud superior del Caribe colombiano. Revista de Biologia Tropical 53: 171-194.

Benavides-Serrato M, Borrero-Pérez GH, Dias Sanchez CM (2011) Equinodermos del Caribe colombiano I: Crinoidea, Asteroidea y Ophiuroidea. Serie de Publicaciones Especiales de Invemar, 22. Santa Marta, $384 \mathrm{pp}$.

Bernasconi I (1941) Dos nuevas especies argentinas de Luidia. Physis 19: 117-118.

Bernasconi I (1942) Los Asteroideos sulamericanos de la família Luidiidae. Physis 19: 252-253.

Bernasconi I (1943) Los Asteroideos sulamericanos de la família Luidiidae. Anales del Museo Argentino de Ciencias Naturales (7): 1-20.

Bernasconi I (1955) Equinoideos y Asteroideos de la Colección del Instituto Oceanografico de la Univerdidad de San Pablo. Primera contribución. Boletim do Instituto Oceanográfico 6: 51-57. doi: 10.1590/S0373-55241955000100002

Bernasconi I (1956) Dos nuevos Equinodermos de la costa del Brasil. Neotropica 2: 33-36. Bernasconi I (1957) Equinoideos y Asteroideos de la Colección del Instituto Oceanografico de la Univerdidad de San Pablo. Segunda contribución. Boletim do Instituto Oceanográfico 7: 119-148. doi: 10.1590/S0373-55241956000100008

Boone L (1933) Scientific results of cruises of the Yachts Eagle and Ara, 1921-1928, Willian K. Vanderbilt Commanding. Coelenterata, Echinodermata, and Mollusca. Bulletin Vanderbilt Marine Museum 4: 1-217.

Brito IM (1960) Asteróides dos Estados do Rio de Janeiro e de Sáo Paulo. Universidade do Brasil, Faculdade Nacional de Filosofia, Centro de Estudos Zoológicos (5): 1-13.

Brito IM (1962) Ensaio de catálogo dos equinodermas do Brasil. Universidade do Brasil, Faculdade Nacional de Filosofia, Centro de Estudos Zoológicos (13): 1-10.

Brito IM (1968) Asteróides e equinóides do Estado da Guanabara e adjacências. Boletim do Museu Nacional (260): 1-51.

Brito IM (1971) Contribuição ao conhecimento dos equinodermas da Ilha da Trindade. Arquivos do Museu Nacional 54: 261-265.

Brögger MI, Penchaszadeh PE (2008) Infaunal mollusks as main prey for two sand bottoms sea stars off Puerto Quequén (Argentina). Revista de Biologia Tropical 56: 329-334.

Calil P, Rocha RM, Freire CA, Roper J (2009) The role of Asterina stellifera (Echinodermata: Asteroidea) as a predator in a rock intertidal community in Southern Brazil. Zoologia 26: 279-287. doi: 10.1590/S1984-46702009000200010

Carrera-Rodriguez CJ, Tommasi LR (1977) Asteroidea de la plataforma continental de Rio Grande do Sul (Brasil), colecionados durante los viajes del N/Oc. "Prof. W. Besnard" para el proyecto Rio Grande do Sul. Boletim do Instituto Oceanográfico 26: 51-130. doi: $10.1590 /$ S0373-55241977000100004 
Carvalho ALPS, Ventura CRR (2002) The reproductive cycle of Asterina stellifera (Möbius) (Echinodermata: Asteroidea) in the Cabo Frio region, southeastern Brazil. Marine Biology 141: 947-954. doi: 10.1007/s00227-002-0881-y

Clark AH (1939) Echinoderms of the Smithsonian-Hartford Expedition, 1937, with other West Indian records. Proceedings of The United States National Museum 86: 441-456. doi: 10.5479/si.00963801.86-3056.441

Clark AH (1940) Eastern Pacific expeditions of the New York Zoological Society. XXI. Notes on echinoderms from the west coast of Central America. Zoologica 25: 331-355.

Clark AH (1945) A new starfish of the genus Luidia from the coast of Georgia. Journal of the Washington Academy of Science 35: 19-21.

Clark AM (1953) Notes on asteroids in the Bristh Museum (Natural History). 3. Luidia. 4. Tosia and Pentagonaster. Bulletin of the British Museum Natural History (Zoology) 1: 379-412.

Clark AM (1982) Notes on Atlantic Asteroidea 2. Luidiidae. Bulletin of the British Museum, Natural History 42: 157-184.

Clark AM, Downey ME (1992) Starfishes of the Atlantic. Chapman \& Hall Identification Guides, 3. Chapman \& Hall, London, UK. ISBN 0-412-43280-3, 820 pp.

Clark AM, Courtman-Stock J (1976) The echinoderms of southern Africa. British Museum (Nat. Hist), London, 277 pp.

Clark HL (1942) The echinoderm fauna of Bermuda. Bulletin of the Museum of Comparative Zoology 89: 367-391.

Coutinho PN (2006) Oceanografia Geológica. Região Nordeste. Programa REVIZEE-Levantamento do Estado da Arte da Pesquisa dos Recursos Vivos Marinhos do Brasil. Relatório apresentado ao Ministério do Meio Ambiente, dos Recursos Hidrícos e da Amazônia Legal-MMA.

del Valle García R, Abreu Pérez M, Rodríguez R, Solís-Marín FA, Laguarda-Figueras A, Duran González A de la L (2008) Equinodermos (Echinodermata) del occidente del Archipiélago Sabana-Camagüey, Cuba. Revista de Biologia Tropical 56: 19-35.

Döderlein L (1917) Die Asteriden der Siboga-Expedition. I. Die Gattung Astropecten und ihre Stammesgeschichte. Sibog-Exped 46a: 1-190.

Downey ME (1973) Starfishes from the Caribbean and the Gulf of Mexico. Smithson Contribution to Zoology 126: 1-168. doi: 10.5479/si.00810282.126

Engel H, John DD, Cherbonnier G (1948) The genus Mithrodia Gray, 1840. Zoologische Verhandelingen 2: 1-40.

Fernandes MLB, Tommasi LR, Lima EJB (2002) Filo Echinodermata de Pernambuco. In: Tabarelli M, Silva JMC (Orgs) Diagnóstico da Biodiversidade de Pernambuco. Vol. 2. Massangana, Recife, 405-427.

Fisher WK (1919) Starfishes of the Philippine seas and adjacent Waters. Bulletin of the United States National Museum 3: 1-547.

Fisher WK (1926) Notes on the Asteroidea. Annals \& Magazine of Natural History 18: 196200. doi: 10.1080/00222932608633495

Gibran FZ (2002) The sea basses Diplectrum formosum and D. radiale (Serranidae) as followers of the sea star Luidia senegalensis (Asteroidea) in southeastern Brazil. Brazilian Journal of Biology 62: 591-594. doi: 10.1590/S1519-69842002000400005 
Gondim AI, Giacometti ACM (2010) Equinodermos. In: Giacometti ACM, Loebmann D (Orgs) Biodiversidade do Litoral do Piauí. Gráfica e Editora Paratodos Sorocaba Ltda, Terrezina, 129-133.

Gondim AI, Lacouth P, Alonso C, Manso CLC (2008) Echinodermata da praia do Cabo Branco, João Pessoa, Paraíba, Brasil. Biota Neotropica 8: 151-159. doi: 10.1590/ S1676-06032008000200016, http://www.biotaneotropica.org.br/v8n2/pt/abstract?inventory+bn02408022008

Gondim AI, Dias TLP, Christoffersen ML (2013) Annotated checklist of Echinoderms from Maranhão and Piauí States, northeastern Brazil. Check List 9: 510-518.

Gould AA (1841) Report on the Invertebrata of Massachusetts. Folson, Wells and Thruston, Cambridge (Mass.).

Gray JE (1840) A synopsis of the genera and species of the class Hypostoma (Asterias Linnaeus). Annals and Magazine of Natural History 6: 175-184. doi: 10.1080/03745484009443282 Gray IE, Downey ME, Cerame-Vivas MJ (1968) Sea-stars of North Carolina. Fishery Bulletin 67: $127-163$.

Grube AE (1857) Diagnosen einiger neuen Echinodermen. Archiv für Naturgechichte 23: 340-344. Guille A, Laboute P, Menou JL (1986) Guide des etoiles de mer, oursins et autres echinodermes du lagon de Nouvelle-Caledonie. Edition de l'Orstom, Paris. Colletion FauneTropicale. № 25. Hadel VF, Monteiro AMG, Ditadi ASF, Thiago CG, Tommasi LR (1999) Echinodermata. In: Migotto AC, Thiago CG (Eds) Biodiversidade do Estado de São Paulo, Brasil: Síntese do Conhecimento ao Final do Século XX, 3: Invertebrados Marinhos FAPESP, São Paulo, 260-271.

Hayashi R (1940) Contributions to the Classification of the sea-star of Japan. Journal of the Faculty of Science Hokkaido 7: 107-204.

Hendler G, Miller JE, Pawson DL, Kier PM (1995) Sea stars, sea urchins and allies: echinoderms of Florida and the Caribbean. Smithsonian Institution Press, Washington, 390 pp. Hopkins TS, Knott KE (2010) The establisment of a neotype for Luidia clathrata (Say, 1825) and a new species within the genus Luidia (Asteroidea: Paxillosida: Luidiidae). In: Harris LR et al. (Eds) Echinoderms: New Hampshire. Proceedings of the 12th International Echinoderm Conference. A. A. Balkema, Rotterdam, 207-212.

Hopkins TS, Fontanella FM, Ventura CRR (2003) Morphological diagnosis of three Brazilian starfish of the genus Echinaster (subgenus Othilia). In: Féral JP, David B (Eds) Echinoderm Research 2001: Proceedings of the 6th European Conference on Echinoderm Research. Balkema, Banyuls-sur-mer, 97-103.

Hotchkiss FHC (2000) On the number of rays in starfish. American Zoology 40: 340-354. doi: 10.1668/0003-1569(2000)040[0340:OTNORI]2.0.CO;2

Jangoux M (1982) Digestive systems: Asteroidea. In: Jangoux M, Lawrence JM (Eds) Echinoderm Nutrition. A.A. Balkema, Balk Rotterdam, 235-272.

Jangoux M, Lawrence JM (1982) Echinoderm Nutrition. A.A. Balkema, Rotterdam, 700 pp. John D (1948) Notes on Asteroidea in the British Museum (Natural History) 1. The species of Astropecten. Novitates Zoolicae 42: 485-508.

John DD, Clark AM (1954) The "Rosaura" expedition. 3. The Echinodermata. Bulletin of the British Museum (Natural History) Zoology 2: 139-162. 
Kascelan S, Mandic S (2007) Diversity and distribution of Asteroidea (Echinodermata) within the Bay of Boka Kotorska (Adriartic Sea, Montenegro). Rapports de la Commission Internationale de la Mer Méditerranée Rapp Comm Int Mer Médit 38: 515.

Kempf M (1966) On the development of Echinaster echinophorus (Lamarck). Anais da Academia Brasileira de Ciências 38: 505-507.

Kempf M, Coutinho PN, Morais JO (1970) Plataforma continental do Norte e Nordeste do Brasil. Trabalhos Oceanográficos da Universidade Federal de Pernambuco 9: 9-15.

Knott KE, Hopkins TS (1998) Morphological and biochemical variation in two color morphs of Luidia clathrata. In: Mooi R, Telford M (Eds) Echinoderms: San Francisco. Proceedings of the 9th International Echinoderm Conference. A. A. Balkema, Rotterdam, 253-257.

Koehler R (1911) Mission Gruvel sur la côte occidental d'Afrique (1909-10): Echinodermes. Annales de l'Institut Océanographique Monaco 5: 1-25.

Krau L (1950) Observação sobre os equinodermas da Baía de Guanabara. Memórias do Instituto Oswaldo Cruz 48: 357-362. doi: 10.1590/S0074-02761950000100013

Lamarck JBPA de (1816) Histoire naturelle des animaux sans vertèbres. Vol. 2. Verdière, Paris.

Lana PC, Camargo MG, Brogim RA, Isaac VJ (1996) O bentos da costa brasileira. Femar, Rio de Janeiro, 432 pp.

Lima EJB, Fernandes MLB (2009) Diversidade de equinodermos (Echinodermata) no Estado de Pernambuco (Brasil). Revista Brasileira de Zoociências 11: 55-63.

Lima-Verde JS (1969) Primeira contribuição ao inventário dos Echinodermas do nordeste Brasileiro. Arquivos de Ciências do Mar 9: 9-13.

Lima-Verde JS, Matthews HR (1969) On the feeding habits of the sea star Luidia senegalensis (Lamarck) in the State of Ceará (Brazil). Arquivos da Estação de Biologia Marinha da Universidade Federal do Ceará 9: 173-175.

Linnaeus C (1753) Museum Tessinianum. Holmiae, 123 pp.

Linnaeus C (1758) Systema naturae per regna tria naturae secundum classes, ordines, genera, species, cum characteribus, differentiis, synonymis, locis. Tomus I. 10th Edition, reformata. Laurentius Salvius, Holmiae, 824 pp.

Loriol P de (1885) Catalogue raisonné des Echinodermes recueillis par M. V. de Robillard à I'lle Maurice. 2. Stellérides. Memoires de la Société de Physique et d'Histoire Naturelle de Genève 29: 1-84.

Lütken C (1859) Bidrag til Kundskab om de ved Kysterne af Mellem-og Syd-Amerika levende Arter af Söstjerner. Videnskabelige Meddelelser Dan. Naturhist. Foren 1859: 25-96.

Lütken C (1872) Fortsatte kritiske org beskrivende Bidrag til Kundskab om Sostjernerne (Asteriderme). Videnskabelige Meddelelser Dan. Naturhist. Foren 1871: 227-304.

Mabesoone JM, Coutinho PN (1970) Littoral and shallow marine geology of Northern and northeastern Brazil. Trabalhos Oceanográficos da Universidade Federal de Pernambuco 12: $1-214$.

Marcgrave G (1648) Historiae rerum naturalium Brasiliae, libri octo. Cum appendice de Tapuyis, et Chilensibus. Ioannes de Laet, Antwerpianus, In ordinem digessit \& annotationes addidit, \& varia ab auctore omissa supplevit \& illustravit. In: Piso W, Macgrave G. Historia naturalis Brasiliae: in qua non tantum plantae et animalia, sed et indigenarum morbi, ingenia et mores describuntur et iconibus supra quingentas illustrantur. Lugdun. 
Batavorum: Apud Franciscum Hackium, et Amstelodami: Apud Lud. Elzevirium. http:// www.botanicus.org/item/31753000818648 [accessed on 2014-03-12]

Machado ABM, Drummond GM, Paglia AP (2008) Livro vermelho da fauna brasileira ameaçada de extinção. Ministério do Meio Ambiente, Brasília. Vol. I. Série Biodiversidade $19,512 \mathrm{pp}$.

Madsen FJ (1947) The echinoderms collected by the Skagerak Expedition in the Eastern Atlantic, 1946. 1. Asteroidea, Ophiuroidea, Echinoidea and Holothuroidea. Meddelanden från Göteborgs Kungliga Vetenskaps- och Vitterhets-Samhälles Handlingar 6B: 1-16.

Madsen FJ (1950) The echinoderms collected by the Atlantide Expedition 1945-46. 1. Asteroidea. Atlantide Report 1: 167-222.

Magalhães WF, Martins LR, Alves OFS (2005) Inventário dos Echinodermata do Estado da Bahia. Brazilian Journal of Aquatic Science and Technology 40: 375-381.

Mah CL, Blake DB (2012) Global diversity and phylogeny of the Asteroidea (Echinodermata). PLoS ONE 7: e35644. doi: 10.1371/journal.pone.0035644

Mah CL (2013) World Asteroidea database. http://www.marinespecies.org/asteroidea [acessed 5 November 2013]

Manso CLC (1989) Os Echinodermata da plataforma continental interna entre Cabo Frio e Saquarema, Rio de Janeiro, Brasil. Revista Brasileira de Biologia 49: 355-359.

Manso CLC (2006) Primeiro registro de Goniasteridae (Echinodermata, Asteroidea) no Cretáceo do Brasil: Turoniano da Bacia Potiguar. Geociências 25: 255-260.

Manso CLC, Alves OF, Martins LR (2008) Echinodermata da Baía de Todos os Santos e da Baía de Aratu (Bahia, Brasil). Biota Neotropica 8: 179-196. doi: 10.1590/S167606032008000300017

Mariante FLF, Lemos GB, Eutrópio FJ, Castro RRL, Gomes LC (2010) Reproductive biology in the starfish Echinaster (Othilia) guyanensis (Echinodermata: Asteroidea) in southeastern Brazil. Zoologia 27: 897-901. doi: 10.1590/S1984-46702010000600010

Marques AC, Lamas CJE (2006) Taxonomia zoológica no Brasil: estado da arte, expectativas e sugestôes de açôes futuras. Papéis Avulsos de Zoologia 46: 139-174.

Martens E (1866) Ueber östasiatische Echinodermem. 3. Seetserme des Indischen Archipel. Archiv für Naturgeschichte 32: 57-88.

Matsubara M, Komatsu MA, Takeyoshi A, Shuichi A, Yokobori S, Watanabe K, Wada H (2005) The phylogenetic status of Paxillosida (Asteroidea) based on complete mitochondrial DNA sequences. Molecular Phylogenetics and Evolution 36: 598-605. doi: 10.1016/j. ympev.2005.03.018

Matthews HR, Lima-Verde JS (1969) Notas sobre Oreaster reticulatus (Linnaues, 1758) no nordeste brasileiro (Echinodermata, Asteroidea). Arquivos da Estação de Biologia Marinha da Universidade Federal do Ceará 8: 223-224.

Maury CM (2002) Avaliação e identificação de áreas e ações prioritárias para a conservação, utilização sustentável e repartição dos benefícios da biodiversidade dos biomas brasileiros. MMA/SBF, 404 pp.

McClintock JB, Lawrence JM (1985) Characteristics of foraging in the soft-bottom benthic starfish Luidia clathrata (Echinodermata: Asteroidea): prey selectivity, switching behavior, functional responses and movement patterns. Oecologia 66: 291-298. 
Migotto AE, Tiago CG (1999) Biodiversidade do Estado de São Paulo. Síntese do Conhecimento ao Final do Século XX. Vol 3. Invertebrados Marinhos. Fundação de Amparo à Pesquisa do Estado de São Paulo, São Paulo, 310 pp.

Miranda ALS, Lima MLF, Sovierzoski HH, Correia MD (2012) Inventory of the Echinodermata collection from the Universidade Federal de Alagoas. Biota Neotropica 12: 135-146. doi: 10.1590/S1676-06032012000200014

Möbius K (1859) Neue Seesterne des Hamburger und Kieler Museums. Abhandlungen und Verhandlungen. Naturwissenschaftlicher Vereins inHamburg 4: 1-14.

Monteiro AMG, Pardo EV (1991) Dieta alimentar de Astropecten marginatus e Luidia senegalensis (Echinodermata-Asteroidea). Revista Brasileira de Biologia 54: 49-54.

Mortensen T (1933) The Echinoderms of St. Helena (other than crinoids). Videnskabelige Meddelelser fra Dansk naturhistorisk Forening 93: 401-472.

Müller J, Troschel FH (1842) System der Asteriden. Braunschweig: xx+134, 12 pls.

Müller J, Troschel FH (1843) Neue Beiträge zur Kenntnis der Asteriden. Archiv für Naturgeschichte 9: 113-131.

Nardo JD (1834) De Asteriis. Isis, Jena. Encyclopaedische Zeitung, 716-717.

Netto LF (2006) Echinodermata do Canal de São Sebastião, São Sebastião (SP). Dissertation, University of São Paulo.

Nobre CC, Campos-Creasey LS (2000) Efeito da salinidade no desenvolvimento larval de Echinaster echinophorus (Lamarck 1816) (Echinodermata: Asteroidea). Notas Técnicas do Facimar 4: 61-68.

Nomura H, Fausto Filho J (1966) Shrimp survey in coastal and offshore waters of northeastern Brazil. Arquivos da Estação de Biologia Marinha da Universidade Federal do Ceará 6: $15-29$.

Oliveira HP (1940) Notas sobre os asteróides brasileiros (espécies da Guanabara). Boletim do Ministério de Agricultura 29: 17-30.

Oliveira JP, Oliveira J, Manso CLC (2010) Inventário da coleção de equinodermos do LABIMAR, Campus Prof ${ }^{\circ}$. Alberto Carvalho, Universidade Federal de Sergipe. Scientia Plena 6: $1-14$.

O'Loughlin PM (2002) New genus and species of southern Australian and Pacific Asterinidae (Echinodermata, Asteroidea). Memoirs of Museum Victoria 59: 277-296.

O'Loughlin PM, Waters JM (2004) A molecular and morphological revision of genera of Asterinidae (Echinodermata: Asteroidea). Memoirs of Museum Victoria 61: 1-40.

Ortega I, Martín A, Díaz Y (2010) Distribución, parámetros poblacionales y dieta de Astropecten marginatus (Asteroidea: Astropectinidae) en el Atlántico venezolano. Revista de Biologia Tropical 59: 53-69.

Pawson DL, Vance DJ, Messing CG, Solís-Marín FA, Mah CL (2009) Echinodermata of the Gulf of Mexico. In: Felder DL, Camp DK (Eds) Gulf of Mexico: origin, waters, and biota. Vol. 1. Biodiversity. Texas A\&M University Press, College Station, 1177-1204.

Penchaszadeh PE (1973) Comportamiento trófico de la estrela de mar Astropecten brasiliensis. Ecologia 1: 45-54.

Penchaszadeh PE, Lera ME (1983) Alimentación de três espécies tropicales de Luidia (Echinodermata, Asteroidea) em Golfo Triste, Venezuela. Caribbean Journal of Science 19: 1-6. 
Perrier E (1869) Recherches sur les pédicellaires et les ambulacres des astéries et des oursins.

Thesis. Victor Masson et Fills, Paris, 188 pp.

Perrier E (1875) Revision de la collection de Stellérides du Muséum d'Histoire Naturelle de Paris. Reinwald, Paris, 384 pp.

Perrier E (1881) Reports on the results of dredging by the United States coast survey Steaner

"Blake". XIV. Description sommaire des spèces nouvelles d'Astéries. Bulletin of the Museum of Comparative Zoology 9: 1-31.

Perrier E (1894) Stellérides. Expéditions Scientifiques du Travailleur et du Talisman, Masson, Paris 3: 1-431.

Pinheiro LS, Coriolano LN, Costa MF, Dias JA (2008) O nordeste brasileiro e a gestão costeira. Revista de Gestão Costeira Integrada 8: 5-10. doi: 10.5894/rgci58

Pope EC, Rowe FWE (1977) A new genus and two new species in the family Mithrodiidae

(Echinodermata: Asteroidea) with comments on the status of species of Mithrodia Gray, 1840. Australian Zoology 19: 201-216.

Rathbun R (1879) A List of the Brazilian echinoderms, with notes on their distribution, etc.

Transactions of the Connecticut Academy of Arts and Science 5: 139-151.

Retzius AJ (1805) Dissertatio sistens species cognitas. Asteriarum. Lundae, 37 pp.

Say T (1825) On the species of the linnean genus Asterias inhabiting the coast of the United

States. Journal of the Academy of Natural Sciences of Philadelphia 5: 151-154.

Scheibling RE (1980) Abundance, spatial distribution, and size structure of populations of

Oreaster reticulatus (Echinodermata: Asteroidea) on sand bottoms. Marine Biology 57:

107-119. doi: 10.1007/BF00387376

Sladen WP (1882) The Asteroidea of H.M.S. Challenger Expedition. (Preliminary notices). 1.

Pterasteridae. Zoological Journal of the Linnean Society 16: 186-246.

Sladen WP (1883) The Asteroidea of H.M.S. Challenger Expedition. (Preliminary notices). 2.

Astropectinidae. Zoological Journal of the Linnean Society 17: 214-269. doi: 10.1111/ j.1096-3642.1883.tb02022.x

Sladen WP (1889) Report on the Asteroidea collected by H.M.S. 'Challenger' during the years 1873-1876. Report Scientia Results Voyage Challenger, Zoology 30: 1-935.

Sluiter CP (1895) Die Asteriden Sammlung des Museums zu Amsterdam. Bijdragen tot de Dierkunde 17: 49-64.

Studer T (1884) Verzeichnis der während der Reise S.M.S. Gazelle um die Erde, 1874-76 gesammelten Asteriden und Euryaliden. Abhandlungen der Preussischen Akademie der Wissenschaften 2: 1-64.

Suguio K (2003) Tópicos de geociências para o desenvolvimento sustentável: as regióes litorâneas. Revista do Instituto de Geociências da USP, São Paulo 1: 1-40.

Tommasi LR (1958) Os equinodermos do litoral de São Paulo. Contribuiçóes do Instituto Oceanográfico, Universidade de São Paulo (2): 1-27.

Tommasi LR (1966) Sobre alguns Equinodermas da região do Golfo do México e do Mar das Antilhas. Anales del Instituto de Biologia 1/2: 155-165.

Tommasi LR (1970) Lista de asteróides recentes do Brasil. Contribuiçóes do Instituto Oceanográfico, Universidade de São Paulo (18): 1-61. 
Tommasi LR (1985) Equinodermes da região da Ilha da Vitória (SP). Relatórios Internos do Instituto Oceanográfico, Universidade de São Paulo (13): 1-5.

Tommasi LR, Castro, SM, Sousa EC (1988) Echinodermata coletados durante as campanhas oceanográficas do N/Oc. "Almirante Saldanha" no Atlântico Sul Ocidental. Relatórios Internos do Instituto Oceanográfico, Universidade de São Paulo (21): 1-11.

Tommasi LR (1999) Echinodermata recentes e fósseis do Brasil-Base de Dados Tropical. http://www.bdt.org.br/zoologia/echinodermata [acessed 10 May 2005]

Tommasi LR, Aron MA (1987) Equinodermes dos bancos submarinos da cadeia de montanhas Vitória-Trindade. Relatórios Internos do Instituto Oceanográfico, Universidade de São Paulo (18): 1-9.

Tommasi LR, Aron MA (1988) Equinodermes da plataforma continental do sudeste do estado da Bahia. Relatórios Internos do Instituto Oceanográfico, Universidade de São Paulo (19): 1-6. Tortonese E (1956) Si alcune di Astropectinidae, con descrizione di una nuovo Astropecten (Asteroidea). Annali del Museo Civico di Storia Naturale di Genova 68: 319-334.

Ventura CRR, Fernandes FC (1995) Bathymetric distribution and population size structure of paxillosid sea-stars (Echinodermata) in the Cabo Frio upwelling ecosystem of Brazil. Bulletin of Marine Science 56: 268-282.

Ventura CRR, Falcão APC, Santos JS, Fiorl CS (1997) Reproductive cycle and feeding periodicity in the starfish Astropecten brasiliensis in the Cabo Frio upwelling ecosystem (Brazil). Invertebrate Reproduction and Development 31: 135-141. doi: 10.1080/07924259.1997.9672571

Ventura CRR, Veríssimo I, Nobre CC, Zama PC (2007) Filo Echinodermata. In: Lavrado HP, Viana MS (Eds) Atlas de invertebrados marinhos da região central da zona econômica exclusiva brasileira. Parte 1. Museu Nacional, Rio de Janeiro, (Série Livros, 25).

Ventura CRR, Borges M, Campos LS, Costa-Lotufo LV, Freire CA, Hadel VF, Manso CLC, Silva JRMC, Tavares Y, CG Tiago CG (2012) Echinoderm from Brazil: Historical research and the current state of biodiversity knowledge. In: Alvarado JJ, Sólis-Marin FA (Orgs) Echinoderm Research and Diversity in Latin America. 1ed. Springer, Berlin, 301-344.

Verrill AE (1867) Notes on the Radiata in the Museum of Yale College. Transactions Connecticut Academy Arts \& Sciences 1: 247-351.

Verrill AE (1868) Notice on the corals and echinoderms collected by Prof. C.F. Hartt at the Abrolhos Reefs, Province of Bahia, Brasil, 1867. Transactions of the Connecticut Academy of Arts and Science 1: 351-371.

Verrill AE (1870) Notice on the echinoderms of Panama and the West coast of America. Transactions of the Connecticut Academy of Arts and Sciences 1: 251-322.

Verrill AE (1907) The Bermuda Island. 5(1). Characteristic life of the Bermuda coral reef. Transactions of the Connecticut Academy of Arts and Sciences 12: 204-348.

Verrill AE (1913) Revision of the genera of starfishes of the subfamily Asterininae. American Journal of Science 35: 477-485. doi: 10.2475/ajs.s4-35.209.477

Verrill AE (1914) Monograph of the shallow-water starfishes of the North Pacific coast from the Arctic Ocean to California. Smithsonian Institution, Harriman Alaska Series 14: 1-408. 
Verrill AE (1915) Report on the starfishes of the West Indies, Florida, and Brazil, including those obtained by Bahamas Expedition from the University of Iowa in 1893. Bulletin from the Laboratories of Natural History of the State University of Iowa 7: 1-232.

Viller L, Blake DB, Jagt JWM, Kutscher M (2004) A preliminary phylogeny of the Pterasteridae (Echinodermata, Asteroidea) and the first fossil record: Late Cretaceous of Germany and Belgium. Palaontologische Zeitschrift 78: 281-299. doi: 10.1007/BF03009226

Walenkamp JHC (1976) The asteroids of the coastal waters of Surinam. Zoologische Verhandelingen 147: 1-91.

Walenkamp JHC (1979) Asteroidea (Echinodermata) from the Guyana shelf. Zoologische Verhandelingen 170: 1-97.

Waters JM, Roy MS (2003) Global phylogeography of the fissiparous sea-star genus Coscinasterias. Marine Biology 142: 185-191.

Wells HW, Wells MJ, Gray E (1961) Food of the sea-star Astropecten articulatus. Biological Bulletin 120: 265-271. doi: 10.2307/1539382

Xavier LAR (2010) Inventário dos equinodermos do Estado de Santa Catarina, Brasil. Brazilian Journal of Aquatic Science and Technology 14: 73-78. doi: 10.14210/bjast.v14n2.p73-78

Zoppi de Roa E (1967) Contribuicion al estudio de los equinodermos de Venezuela. Acta Biologica Venezuelica 5: 267-333.

Zulliger DE, Lessios HA (2010) Phylogenetic relationships in the genus Astropecten Gray (Paxillosida: Astropectinidae) on global scale: molecular evidence for morphological convergence, species-complexes and possible cryptic speciation. Zootaxa 19: 1-19. 